\title{
Volume Dynamics and Multimarket Trading
}

\author{
Michael Halling \\ Pamela C. Moulton \\ Marios Panayides*
}

October 13, 2011

forthcoming, Journal of Financial and Quantitative Analysis

Keywords: Multimarket trading, Cross-listing, Trading volume, Integration

JEL Classifications: G15, G19

\footnotetext{
* Halling is at University of Utah, michael.halling@business.utah.edu; Moulton is at Cornell University, pmoulton@cornell.edu; and Panayides is at University of Pittsburgh, mpanayides@katz.pitt.edu. We thank an anonymous referee, Ihsan Badshah, Leonce Bargeron, Shmuel Baruch, Hank Bessembinder, Stephen Brown (the editor), Tarun Chordia, Darwin Choi, Paul Moon Sub Choi, Thierry Foucault, Louis Gagnon, Diego Garcia, Eric Hughson, Pankaj Jain, Avner Kalay, Andrew Karolyi, Aditya Kaul, Mike Lemmon, George Nissiotis, Paolo Pasquariello, Ionid Rosu, Gideon Saar, Asani Sarkar, Elvira Sojli, Shawn Thomas, Lenos Trigiorgis, Kumar Venkataraman, Ingrid Werner, Leyuan Wendy You, and seminar participants at HEC Paris, Ohio State University, University of Cyprus, University of North Carolina, University of Pittsburgh, University of Utah, the 2011 American Finance Association Annual Meetings, the 2010 European Winter Finance Summit, the 2009 Financial Intermediation Research Society Conference, the 2009 Financial Management Association Conference, the 2009 Financial Management Association European Conference, the 2009 Mid-Atlantic Research Conference in Finance, and the 2008 Northern Finance Association Meetings for helpful comments. We thank Bob Keays and Don Schnedeker for excellent research assistance.
} 


\title{
Volume Dynamics and Multimarket Trading
}

\author{
Abstract \\ The trading of shares of the same firm in multiple markets has become common over the \\ last thirty years, but there is little empirical evidence on the extent to which investors actively \\ exploit multimarket environments. We introduce a volume-based measure of multimarket \\ trading to address this question. Analyzing a large set of cross-listed firms, we find higher \\ multimarket trading among markets with similar designs and strong enforcement of insider \\ trading laws and for firms with higher institutional ownership. These findings are important for \\ firms evaluating the benefits of cross-listing and for markets competing for order flow.
}




\section{Introduction}

Whenever the stock of one firm is traded on multiple markets, as is the case for firms that list shares on both their domestic market and a cross-listing market, discretionary investors have a choice of where to trade. ${ }^{1}$ Theoretical models show that the optimal choices of discretionary investors (investors who can choose where to trade) may result in an equilibrium consisting of all trading concentrated in one market, most trading concentrated in one market, or substantial trading in both markets. ${ }^{2}$ Yet empirically we have little evidence of the extent to which discretionary investors actively trade in multiple markets and why. As more shares of the same firm are traded in multiple markets (an environment already established in the U.S. and well under way in Europe), it is increasingly important to traders, policymakers, market operators, and issuers whether multimarket trading creates a single integrated market or separate pockets of liquidity. Large traders are concerned about price impact minimization, while policymakers, market operators, and issuers are concerned with market efficiency and overall market quality. ${ }^{3}$ In this paper we examine the dynamics of trading volume in a multimarket setting to capture the degree to which traders actively exploit multimarket environments and treat competing markets as one market. We then identify both market- and firm- level factors that explain variation in multimarket trading across markets and over time. $^{4}$

If there are non-discretionary (captive) liquidity traders in both markets, discretionary liquidity traders and privately informed traders should split their trades across markets and concentrate their trades during overlapping trading hours for many reasons, including to minimize the price impact of their trades, to exploit their informational advantages, to strategically enhance their informational advantages, or to

\footnotetext{
${ }^{1}$ For evidence that investors view domestic and cross-listed stocks of the same firm as close substitutes, see JPMorgan (2003) and Moulton and Wei (2009).

${ }^{2}$ See, for example, Pagano (1989), Chowdhry and Nanda (1991), and Menkveld (2008).

${ }^{3}$ Evidence of the beneficial role of an integrated multimarket trading environment in the U.S. can be found in O'Hara and Ye (2010), who argue that the documented improvement in market quality is due to the integration of trade across multiple trading platforms achieved through regulation (Reg NMS).

${ }^{4}$ Baruch, Karolyi, and Lemmon (2007) and Halling et al. (2008) examine empirically the equilibrium distribution of trading across competing markets, a question which is related to but distinct from ours.
} 
exploit delays in the market's reaction to related information. Thus a demand shock to trade by discretionary traders should lead to higher volume in both markets. Furthermore, a central tenet of financial economics is that arbitrage enforces the law of one price. When temporary mispricings arise between domestic and cross-listed shares, arbitrage activity should lead to a volume shock in both markets. $^{5}$

Motivated by these theories of multimarket trading, we investigate the correlation of trading volume shocks in domestic and cross-listed shares as a potential measure of multimarket trading. We further examine the relation of trading volume shock correlations to multimarket trading barriers and benefits. Explicit (such as little overlap in trading hours) or implicit (such as different market designs) barriers may discourage multimarket traders (trade-splitters and arbitrageurs) from trading in both markets, thereby reducing the correlation of trading volume shocks between markets. Greater potential benefits from multimarket trading should act as catalysts and lead to higher correlations.

Of course, multimarket trading of discretionary traders is not the only possible explanation for such positive volume shock correlations; they could also arise from correlated trading needs of captive investors who respond to public firm-specific news or common economic shocks across markets. We do not expect a priori that the correlation in daily trading volume shocks is driven exclusively by correlated trading needs. Feng and Seasholes (2004) find little evidence of correlated trading needs at the daily level; correlated trading needs generally appear significant only at longer frequencies such as quarterly or monthly. Furthermore, in his study of British cross-listed stocks Menkveld (2008) finds evidence of multimarket trading even after controlling for the possibility of local traders in each market simultaneously receiving the same private signal and trading on it locally.

Empirically, we expect that if correlated trading volume shocks were driven purely by correlated trading needs in the two markets, we should find no relation between the trading volume shock

\footnotetext{
${ }^{5}$ See, for example, Sexton, Kling and Carman (1991), Campbell and Hamao (1992), and Gagnon and Karolyi (2010a).
} 
correlations and multimarket trading barriers and benefits. Multimarket trading barriers and benefits often depend on characteristics of both the domestic and the foreign market (e.g., differences in market design). Captive investors, however, by definition can trade only in their domestic market and thus consider only the characteristics of their domestic market. Thus, if correlated trading by captive investors is driving the correlations, our empirical proxies for multimarket trading barriers and benefits should not explain the variation in volume shock correlations. In this case, we could not interpret the correlation of trading volume shocks as a signal of multimarket trading.

We analyze trading in the stocks of 361 firms from 24 countries that are cross-listed in the United States between 1980 and 2001. We first estimate a vector autoregression (VAR) model for each firm each year to estimate daily unexpected trading volume in the domestic and cross-listing markets. The model controls for possible order flow commonalities across markets and simultaneous trading by captive investors in both markets. The residuals from the VAR are our measures of daily trading volume shocks, and the correlation between the residuals from the domestic and cross-listing markets is our proposed measure of multimarket trading. The average correlation in our sample is 0.28 , and 88 percent of the firmyear correlations are different from zero at the five percent level of significance. The correlations rise substantially over our sample period, especially between emerging markets and the U.S. but also for many developed markets and the U.S.

In a multivariate framework, we find that the degree to which trading volume shocks in domestic and cross-listed shares are correlated depends on market-level barriers and benefits to multimarket trading. The markets in our sample generally do not have explicit government or regulatory barriers to multimarket trading. ${ }^{6}$ The barriers and benefits we examine arise from market structure and the regulatory environment. For example, markets with more overlapping trading hours and no short-sale constraints

\footnotetext{
${ }^{6}$ Bekaert, Harvey, and Lumsdaine (2002a,b) investigate changes in explicit barriers to multimarket trading by analyzing the impact of official capital market reforms on the level of integration of emerging markets. All markets that we investigate are open to foreign investments not only through the ADR market but also in their domestic markets. Our primary focus is the extent to which investors are able and willing to trade in both markets.
} 
generally have higher correlations, consistent with our expectation that these features facilitate tradesplitting and arbitrage across markets. Similarly, we find higher trading volume shock correlations when the domestic and cross-listing markets have similar market designs and stronger enforcement of insider trading laws.

We also examine whether firm characteristics play an important role in multimarket trading. ${ }^{7}$ There is significant variation in the correlation of trading volume shocks across firms from the same country. At the firm level, correlations are higher for stocks that are actively traded in both markets, a situation likely to make both trade-splitting and arbitrage easier. Correlations are also higher for firms with more institutional investors (who are more likely than retail investors to engage in multimarket trading) and for firms that are technology-oriented, which tend to be more successful in creating an active market in their cross-listed shares (Halling et al. (2008)).

An important question is how multimarket trading relates to price integration. The extant literature on price integration tests whether assets with similar risk exposure earn similar expected returns in different national markets. ${ }^{8}$ A key observation from our study is that multimarket trading captures an additional dimension of the broad concept of financial market integration, one that is not fully captured by the extent to which prices of identical assets are close (price integration). ${ }^{9}$ We provide empirical evidence that markets with high levels of multimarket trading, measured by trading volume shock correlations, consistently exhibit small price discrepancies, quantified by the Gagnon and Karolyi (2010a) price disparity measure. However, price integration may occur without actual multimarket trading if there is a credible threat of its occurrence should prices diverge. Our multimarket trading measure thus captures a

\footnotetext{
${ }^{7}$ Gagnon and Karolyi (2009) find that firm-specific characteristics in addition to market characteristics explain the extent of price disparities for a sample of cross-listed stocks. In earlier studies, Jorion and Schwartz (1986) and Mittoo (1992) also consider firm-specific characteristics in the context of market integration.

${ }^{8}$ See, e.g., Bekaert and Harvey (1995), Bekaert, Harvey, and Ng (2005), Bekaert, Harvey, Lundblad, and Siegel (2008) and Pukthuanthong and Roll (2009).

${ }^{9}$ Previous studies of cross-listings have shown that most domestic and cross-listing markets are highly integrated from a pricing perspective at both the daily and the intraday frequency (e.g., Werner and Kleidon (1996), Kim, Szakmary, and Mathur (2000), Hupperets and Menkveld (2002), and Gagnon and Karolyi (2010a)).
} 
different dimension that complements the existing evidence on price integration. Compared to tests of price integration that rely on a specific asset pricing model and face a joint hypothesis problem, our multimarket trading measure is also a simple, intuitive, and model-free metric that requires only daily volume data to estimate.

Our study has important implications for firms considering the value of cross-listing. In an application of our multimarket trading measure, we show that the degree of multimarket trading after a firm cross-lists is strongly related to the improvement in liquidity enjoyed by the firm after cross listing. If a firm's goal in cross-listing is to create a global trading environment for its shares, it would do well to examine the trading barriers and benefits of potential cross-listing venues. Firms with a more integrated trading environment generally have more institutional investors. As Boehmer and Kelley (2009) show, higher institutional participation improves market quality and market efficiency. As a result prices are closer to fundamentals and exhibit lower idiosyncratic volatility. Such improvements in liquidity can lower a firm's cost of capital. Furthermore, our results regarding market features that are instrumental in creating an integrated multimarket trading environment should be of interest to countries and exchanges seeking to attract more volume and increase their market share.

Finally, by analyzing a large sample of firms over many years, we reveal a rich set of market- and firm-level determinants of multimarket trading. We explicitly evaluate the sources of variation in the level of multimarket trading across firms as well as across markets. To our knowledge, this is the first paper to address these issues. For example, Menkveld (2008) tests his theoretical model empirically using 25 British and four Dutch stocks cross-listed on the New York Stock Exchange (NYSE). While Menkveld (2008) proxies for the fraction of non-discretionary traders on the NYSE, his study design does not allow for a broader analysis of market-level or firm-level factors.

The organization of the paper is as follows. Section II reviews the theoretical literature on multimarket trading and develops the research hypotheses. Section III discusses the sample and data. Section IV analyzes trading volume shock correlations. Section V examines the relation between trading 
volume shock correlations and multimarket trading barriers and benefits. Section VI compares trading volume shock correlations to other measures of integration at the market level. Section VII examines the relation between multimarket trading and liquidity for firms around their cross-listing dates. Section VIII concludes. The Appendix contains a detailed discussion of the rationale for and calculation of each proxy for multimarket trading barriers and benefits.

\section{Background and Hypothesis Development}

The mere cross-listing of stocks does not guarantee that multimarket trading will occur. For example, Pagano (1989) identifies a winner-takes-all equilibrium when there are no frictions protecting one market. His intuition is that positive trading externalities favor the concentration of trading in one market, because the presence of more traders provides better liquidity for any one order. In this case, we would see no correlation between trading volume shocks in the two markets, which functions as a natural null hypothesis for our study.

Several models of the equilibrium distribution of trading volume across markets are based on the intuition that traders are motivated to split their trades across markets to enhance their welfare. In addition to his winner-takes-all equilibrium, Pagano (1989) identifies an equilibrium in which two markets can coexist when there are trading frictions. Chowdhry and Nanda (1991) derive winner-takes-most equilibria when each market has a certain fraction of noise traders who must trade in their home market. Both of these models assume that trading hours for the two competing markets coincide perfectly. Menkveld (2008) models the equilibrium distribution of trading between a domestic market and a cross-listing market with partially overlapping trading hours. ${ }^{10}$ Menkveld combines Admati and Pfleiderer's (1988) intuition that traders tend to concentrate their trades during certain times with Chowdhry and Nanda's (1991) model of multimarket trading. He predicts that if there are some non-discretionary liquidity traders in each market, discretionary liquidity traders and informed traders will split their trades across markets

\footnotetext{
${ }^{10}$ For example, the London Stock Exchange is open from 8:00 to 16:30 Greenwich Mean Time (GMT) while the New York Stock Exchange is open from 14:30 to 21:00 GMT (9:30 to 16:00 Eastern time), producing a two-hour overlap.
} 
and concentrate their trades during overlapping trading hours. Empirical evidence of investors splitting their trades across domestic and cross-listing markets to minimize their price impact is presented by Chakravarty, Chiyachantana, and Jiang (2011) and by Menkveld (2008), who documents order-splitting by both informed traders and large liquidity traders.

When there are frictions such as differential trading costs between markets, traders may be motivated to trade in both the domestic and cross-listing markets for many different reasons. Sophisticated traders may trade similar assets in different markets in search of the most liquid venue to exploit their informational advantages (Chowdhry and Nanda (1991)), to strategically enhance those advantages (Pasquariello and Vega (2010)), or to exploit delays in the market's reaction to related information (Cohen and Frazzini (2008)). Traders may also be motivated to allocate their trading among similar assets because of rebalancing considerations (Kodres and Pritsker (2002)), information asymmetry (King and Wadhwani (1990)), financial constraints (Kyle and Xiong (2001), Yuan (2005)), or strategic considerations (Caballe and Krishnan (1994), Pasquariello (2007)).

Arbitrage opportunities can provide an additional motivation for sophisticated traders to engage in multimarket trading (Baruch, Karolyi, and Lemmon (2007)). Gagnon and Karolyi (2010a) document that mispricings between the shares of the same firm trading in its domestic market and a cross-listing market occasionally occur (see also Chan, Hong and Subrahmanyam (2008)), and Menkveld (2008) finds evidence of arbitrage activity in intraday trading. Gagnon and Karolyi (2010a) also find that arbitrage is impeded by institutional and informational barriers that prevent arbitrageurs from fully eliminating mispricings between markets.

Although sophisticated traders potentially trade in multiple markets to increase their welfare, that does not imply that trading volumes should be the same in domestic and cross-listing markets. The equilibrium distribution of trading volume may be all in one market, all in the other, or any distribution in between. But all types of multimarket trading should contribute to a positive correlation in trading volume shocks, or unexpected trading volume, in domestic and cross-listed shares if there is a demand to trade by 
discretionary traders and each market has some non-discretionary traders, i.e., there are some investors who trade only the domestic or only the cross-listed shares. ${ }^{11}$ From these predictions we construct the following hypothesis:

Hypothesis 1: Multimarket trading should lead to a positive correlation between trading volume shocks in a firm's domestic and cross-listed shares.

Multimarket trading is not the only possible cause of a positive correlation between trading volume shocks in two markets. The main alternative hypothesis is that positive correlation could be driven by correlated trading needs of captive investors who each trade in only one market. Such correlation in trading needs might be driven by investors' reactions to public firm-specific news or common economic shocks across markets. The correlation of trading volume shocks is an appropriate measure of multimarket trading only if it reflects multimarket trading, not merely correlated trading needs. A key difference is that if the positive correlation between trading volume shocks is driven by multimarket trading, the degree of correlation should be related to the presence of barriers to and benefits from multimarket trading, which should not affect trading driven purely by correlated trading needs in the two markets. We thus formulate the following hypothesis:

Hypothesis 2: If the correlation between trading volume shocks on the domestic and cross-listing markets is driven by multimarket trading, it should vary with the barriers and benefits to multimarket trading.

In a world where all discretionary trading is split across markets to interact with non-discretionary traders in different markets, the correlation should be higher than when barriers discourage trade-splitting and arbitrage across markets. Thus we expect trading volume shock correlations to be lower (higher) when there are greater barriers (potential benefits) to multimarket trading across the domestic and crosslisting markets. For example, if the trading hours in the domestic and cross-listing markets overlap very

\footnotetext{
11 JPMorgan (2003) finds evidence that some investors trade only cross-listed shares and some investors trade only domestic shares of firms located outside the U.S.
} 
little, it is more difficult to minimize price impact by trading in both markets, to exploit delays in the market's reaction to related information, or to exploit temporary mispricings through arbitrage.

\section{Sample and Data}

\section{A. Sample}

We begin with the home-market and cross-listed shares of all firms whose common stock is crosslisted on the New York Stock Exchange, NASDAQ, or the American Stock Exchange at any time between 1980 and 2001. Because the theoretical basis for both trade-splitting and arbitrage relies on simultaneous trading in the domestic and cross-listing markets, we include in our sample only firms for which domestic and cross-listing market trading hours overlap. Our sample is further limited to stocks for which daily trading volume and price data in both the domestic and the cross-listing market are available from Thompson Financial Datastream and Reuters Equity 3000, and both the domestic and cross-listed stocks have enough daily trading data to allow estimation. Our resulting sample includes 361 firms from 24 countries; descriptive statistics are presented in Table 1 . The largest number of firms in our sample are from Canada (186 firms) and the U.K. (48 firms). Daily dollar trading volume is higher in the domestic market than in the cross-listing market for most countries, with notable exceptions including Ireland, Israel, and several Latin American countries.

\section{[Table 1 Here]}

\section{B. Trading Volume}

For each cross-listed company each day, we calculate the daily U.S. dollar volume on the domestic and the cross-listing market as the number of shares traded times the closing price, converting domesticcurrency values to U.S. dollars at the daily closing foreign exchange rate from Thompson Financial Datastream and Reuters Equity 3000. By calculating volume in dollars rather than in shares, we automatically adjust for the American Depositary Receipt (ADR) ratio, since the ADR price reflects the number of domestic shares represented by the ADR. All of our results are robust to an alternative 
specification that uses the number of shares traded per day as the measure of volume; results are available on request. Analyzing daily changes within each market resolves the issue of the ADR ratios in this case.

\section{Trading Volume Shock Correlations}

The hypotheses we want to test most naturally apply to shocks in trading volume (unexpected trading volume) rather than to the level of trading volume. We use a Vector Autoregression (VAR) framework to model expected trading volume in one market as a function of past trading volume in both markets; the residual from each equation captures the trading volume shocks, or unexpected volume, in that market. In the VAR we want to control for unexpected volume that may be unrelated to multimarket trading. We do not want to control for factors such as commonality in liquidity in the VAR, because they are likely to be associated with the multimarket trading we are trying to detect. In particular, for each firm $i$ each year, we estimate the following VAR from trading volume measured at the daily frequency, $t$ :

$$
\begin{gathered}
\operatorname{TVol}_{i, t}^{\mathrm{DOM}}=\alpha_{i}^{\mathrm{DOM}}+\sum_{k=1}^{K} \gamma_{i}^{\mathrm{DOM}, k} \mathrm{TVol}_{i, t-k}^{\mathrm{DOM}}+\sum_{l=1}^{L} \beta_{i}^{C L, l} \operatorname{TVol}_{i, t-l}^{C L}+\sum_{m=1}^{4} \delta_{m, i} \text { Control }_{m, i, t}+\varepsilon_{i, t}^{D O M} \\
\operatorname{TVol}_{i, t}^{C L}=\alpha_{i}^{C L}+\sum_{k=1}^{K} \gamma_{i}^{C L, k} \operatorname{TVol}_{i, t-k}^{C L}+\sum_{l=1}^{L} \beta_{i}^{D O M, l} \operatorname{TVol}_{i, t-l}^{D O M}+\sum_{m=1}^{4} \delta_{m, i} \operatorname{Control}_{m, i, t}+\varepsilon_{i, t}^{C L},
\end{gathered}
$$

where $\mathrm{TVOl}_{i, t}$ is the trading volume change, measured as the logarithm of the ratio of day $t$ to day $t-1$ dollar trading volume. ${ }^{12}$ We use trading volume changes to achieve stationarity because daily volume tends to be quite persistent (see, for example, Chordia, Roll, and Subrahmanyam (2001) and Sanders and Zdanowicz (1992)). ${ }^{13}$ The superscript DOM denotes the domestic market and the superscript $C L$ denotes the cross-listing market. The numbers of lags, $K$ and $L$, are determined per firm and per year using the Akaike Information Criterion (AIC). Our four Control variables are designed to control for unexpected volume that may be unrelated to multimarket trading. Our first control variable is the firm's stock return

\footnotetext{
${ }^{12}$ Ajinkya and Jain (1989) find that raw trading volume data are highly non-normal, so they recommend performing studies on the log transformed variable.

13 Augmented Dickey-Fuller Tests confirm that our transformed volume variable is stationary. Robustness tests using the logarithm of trading volume instead of volume changes yields qualitatively similar results, which are available upon request.
} 
in the domestic market, since daily volumes may be driven by local investors in both markets simultaneously receiving a firm-specific signal (such as an information event) and trading on it locally. Similarly, our second and third control variables are the log change of market-wide daily dollar volume for the domestic market and the cross-listing market. These variables control for aggregate information (macroeconomic news) or other market-wide events that might also induce some correlation in firmspecific volume shocks without multimarket trading necessarily occurring. Our fourth control variable is the daily currency return between the two markets, in case exchange rate dynamics are responsible for some apparent volume shocks (recall that volume in both markets is measured in U.S. dollars). ${ }^{14,15}$

Table 2 reports average statistics for the VAR described in Equations (1) and (2). We model the daily change in trading volume for each firm each year. For brevity we report the coefficients for only the first lag of each variable; each model includes up to four lags, determined by the AIC.

\section{[Table 2 Here]}

Table 2 highlights several interesting characteristics of trading volume dynamics in a multimarket context. First, autocorrelation coefficients are negative, reflecting the mean-reverting pattern of trading volume. These average autocorrelation coefficients are similar for the domestic and cross-listing markets. Second, cross-market correlation coefficients are on average smaller and less significant than autocorrelation coefficients and are positive in each equation. The positive mean coefficients imply that on average there are positive spill-over effects between the two markets. Third, the VARs perform reasonably well in explaining multimarket trading volume dynamics. On average, the VARs explain 39\% and $34 \%$ of the variation of daily trading volume changes for the domestic and cross-listing markets.

We are interested in whether a trading volume shock in one market is related to the trading volume

\footnotetext{
${ }^{14}$ To the extent that these controls, especially firm-specific returns and market volume, are not completely independent from multimarket trading, including them in the VAR biases our subsequent analysis against finding evidence of multimarket trading.

${ }^{15}$ As a robustness check, we also include day-of-the-week dummies as additional control variables in the VAR (Sanders and Zdanowicz (1992), Ajinka and Jain (1989), and Meulbroek (1990)). Our results are unaffected by the addition of day-of-the-week dummies, so for conciseness we omit them from our main specification. Results are available from the authors on request.
} 
shock in the other market on the same day. Therefore our main variable of interest is not simply the unexpected trading volume in each market, $\varepsilon_{i, t}$, but rather the contemporaneous correlation between the unexpected trading volumes in the two markets. ${ }^{16}$ We calculate yearly correlations between the unexpected trading volume in the domestic and the cross-listing markets, resulting in an unbalanced panel of correlations, with one correlation for each firm each year. Table 3 summarizes these correlations by the percentage of overlap in the trading hours of the cross-listing to the domestic market. On average, the correlation between volume shocks in the two markets is 0.28 , and it is generally increasing in the amount of overlap. ${ }^{17}$ Overall, $88 \%$ of the correlations are significant at the $5 \%$ level. ${ }^{18}$ We include all correlations in the following analyses; for robustness we also replicate our results using only the significant correlations and find similar results (results available on request). These correlations provide strong support for our first hypothesis, that trading volume shocks in a firm's domestic stock market should be positively correlated with trading volume shocks in the cross-listing market. In the following section we examine whether these correlations reflect multimarket trading.

\section{[Table 3 Here]}

\section{Barriers and Benefits to Multimarket Trading}

In this section we analyze the relation between trading volume shock correlations and barriers and potential benefits to multimarket trading, to establish whether the correlated trading volume shocks reflect multimarket trading.

\section{A. Measures and Predicted Signs}

In our sample of stock markets, there are no explicit governmental barriers to multimarket trading.

\footnotetext{
${ }^{16}$ Note that a VAR model is correctly specified even if contemporaneous errors are correlated (see Greene (2003)). It becomes mis-specified only if there is correlation across time (for example, if errors are serially correlated).

${ }^{17}$ In separate tests, we examine the correlation of trading volume shocks for markets with no overlapping trading hours. Consistent with theoretical predictions that the correlations are related to simultaneous trading, the non-overlapping markets exhibit correlations that are considerably lower and less significant.

${ }^{18}$ Significance is determined using Fisher's z-transformation. If c denotes the correlation and $\mathrm{n}$ denotes the degrees of freedom, then the test statistic $\mathrm{t}=\mathrm{n}^{1 / 2} \times \ln [(1+\mathrm{c}) /(1-\mathrm{c})]$ is distributed approximately $\mathrm{N}(0,1)$.
} 
Thus the barriers and benefits we consider are factors that arise from market structure, the regulatory environment, and firm-specific characteristics; the calculation of each variable and the logic behind its predicted sign are explained in the Appendix. At the market level, we expect that a greater overlap in trading hours, more total market volume, stronger protection against insider trading, and the permissibility of short sales would be associated with higher correlations in volume shocks, as they all make it easier for multimarket traders to trade in both markets. In contrast, higher trading cost differences or trading costs in total, more unequal trading volumes on the two markets, and more different market designs may discourage multimarket trading and thus lead to lower volume shock correlations. At the firm level, the more illiquid a firm's stock is on each market and the more unequal the firm's trading volume is on the two markets, the lower the correlation we expect between volume shocks. In contrast, we expect that at the firm level a higher correlation between the stock's return and the cross-listing market's return, a higher Baruch-Karolyi-Lemmon relative information measure (Baruch, Karolyi, and Lemmon (2007)), higher U.S. institutional shareholdings (by percentage or number), higher foreign sales, and a firm's belonging to the technology sector would all lead to higher correlation between the trading volume shocks. Table 4 summarizes the expected influence of each proxy for market- or firm-level barriers and benefits on multimarket trading, as captured by our volume shock correlation measure.

\section{[Table 4 Here]}

Table 5 examines the correlations between all the variables. The first column presents correlations between our measure of trading volume shock correlations (CorrVolChange), proxies for market-level and firm-level barriers and benefits to multimarket trading, and control variables. Most of the marketlevel and firm-level variables (the first 16 rows) display significant correlations with CorrVolChange, and the signs are consistent with the predictions in Table 4. However, the control variables (last three rows) are also highly correlated with CorrVolChange and many of the explanatory variables are highly correlated with each other, so we next examine the relations in a multivariate framework to assess their relative explanatory power. 


\section{[Table 5 Here]}

\section{B. Regression Results}

We estimate the following equation using a random effects regression with robust standard errors: ${ }^{19}$

$$
\begin{aligned}
\text { CorrVolChange }_{i, t}= & \alpha+\sum_{j=1}^{8} \beta_{j} \text { MktLevelVar }_{j, i, t}+\sum_{j=1}^{8} \gamma_{j} \text { FirmLevelVar }_{j, i, t} \\
& +\sum_{j=1}^{4} \lambda_{j} \text { ControlVar }_{j, i, t}+\sum_{j=1}^{21} \delta_{j} \text { Year }_{t, j}+\varepsilon_{i, t}
\end{aligned}
$$

where CorrVolChange $e_{i, t}$ is the trading volume shock correlation based on changes for stock $i$ in year $t$, MktLevelVar is the set of market-level variables, FirmLevelVar is the set of firm-level variables, and Controlvar is the set of control variables in Table 2. We include a series of calendar-year dummy variables, Year, to control for the general increase in integration over our sample period (discussed in Section VI). Since we control for this time trend in our econometric specification, our empirical results explain the trading volume shock correlations in excess of this pure time trend. All explanatory variables except indicator variables are scaled by their standard deviations, so coefficient estimates provide a sense of the explanatory variables' relative impact. We also estimate the regression with subsets of the explanatory variables. ${ }^{20}$

The results from estimating Equation (3) and specifications including subsets of the explanatory variables are presented in Table 6. Specification 1 focuses on the market-level explanatory variables. The significantly positive coefficient estimates on trading hours overlap and short sale permissibility and significantly negative coefficient estimate on market design differences are all consistent with our

\footnotetext{
${ }^{19}$ Estimations from a pooled OLS regression with year fixed effects and Rogers standard errors clustered on firm, as in Petersen (2009), and a pooled OLS regression with standard errors double-clustered on firm and year, as in Thompson (2011), yield qualitatively similar results, which are available on request.

${ }^{20}$ As robustness checks, we run the same regression for the subsample excluding Canadian firms (approximately 50\% of the full sample) and separate cross-sectional regressions each year. Estimations yield qualitatively similar results, which are available on request. When we include foreign exchange volatility as an additional explanatory variable as a robustness check, its coefficient estimate is insignificant and other coefficient estimates are unchanged. To eliminate potential endogeneity, we also estimate equation (3) lagging firm-specific characteristics by one year, which does not change our results. Details of all robustness checks are available from the authors upon request.
} 
predictions of how market-level barriers should affect trading volume shock correlations, as outlined in Table 4. Of these barriers, trading hours overlap has the largest relative effect. A one-standard-deviation increase in trading hours overlap increases the trading volume shock correlation by 0.06 on average, over 20 percent of the average correlation of 0.28 . A difference in market design creates statistically significant barriers between the two markets and decreases the correlation of trading volume shocks by about 0.02 . Specification 1 , which includes only market-level explanatory variables, explains $35 \%$ of the variation in the correlation of trading volume shocks between domestic and cross-listing markets.

\section{[Table 6 Here]}

Specifications 2 and 3 focus on the firm-level barriers and benefits to multimarket trading and also include firm-level control variables. Because foreign sales is a sparsely-populated variable, we exclude it in Specification 3, which expands the number of firm-year observations by about $40 \%$. Excluding foreign sales as an explanatory variable does not change the signs of any other coefficient estimates. Coefficients on all of the firm-level proxies for barriers and benefits to multimarket trading have the predicted signs and many are significant. Lower values of the US Amihud illiquidity measure and a ratio of firm volume across markets that is closer to one (lower FirmVolumeIndex) are associated with higher trading volume correlations (negative coefficients), while the coefficient estimates on the domestic Amihud measure are insignificant, most likely because of multicollinearity with the US Amihud measure (Table 5). Similarly, a higher BKL measure, more U.S. institutional investors (SharesUS and NumberUS), and being in the technology sector are positively related to volume shock correlations. On average, the trading volume shocks of technology firms are 0.05 more correlated than non-technology firms (from specification 3). Firm-level explanatory variables explain 25 to 32 percent of the variation in trading volume shock correlations between domestic and cross-listing markets, depending on whether foreign sales are included as an explanatory variable.

Specification 4 includes market-level and firm-level explanatory variables, omitting the foreign sales variable to maximize the sample size. The results from the first three specifications are consistent with 
those in the full specification, with market-level and firm-level variables remaining consequential for trading volume correlations. Including both market-level and firm-level variables raises the explanatory power to an R-squared of 48 percent. Taken together, these results provide strong support for our second hypothesis that the correlation between trading volume shocks on the domestic and cross-listing markets varies with the level of barriers and benefits to multimarket trading.

Specification 5 extends Specification 4 by also including the lagged dependent variable. Because the volume shock correlation is an autoregressive process, including the lagged dependent variable increases the R-squared to $59 \%$. Adding the lagged dependent variable to the specification also controls for the lagged effect of any variables omitted in the first four specifications. We note that the inclusion of the lagged dependent variable leaves all of our previous results and conclusions unchanged.

The relations between the correlation of trading volume shocks and barriers and benefits to multimarket trading suggest that the correlations are not driven by correlated trading needs of investors who only trade in one of the two markets but not in both. Rather, the results in this section suggest that the correlation of trading volume shocks reflects multimarket trading, indicating the extent to which traders treat separate markets as one integrated market. In the following section we examine what these correlations suggest about integration for different countries and over time.

\section{Multimarket Trading and Integration}

The main goal of this paper is to use trading volume shock correlations to investigate the degree of multimarket trading among international financial markets. Multimarket trading is also likely to be related to integration, although they are not perfectly overlapping notions. In this section, we examine to what extent our multimarket trading measure is distinct from or overlaps with measures of price integration and measures of barriers to broadly defined financial integration.

\section{A. Evidence on Price Integration}

We begin by aggregating our firm-specific measures to market-level measures by country and then 
group them by emerging versus developed countries. Table 7 presents the average trading volume shock correlations for groups of stocks. Panel A presents the average trading volume shock correlations grouped by stocks whose domestic markets are emerging versus developed. Because several countries, including all the emerging markets, have data available only from 1990 on, we divide our sample period into three sub-periods: 1980-1989 (fewer markets available) and two equal-length periods during which data are available for most countries: 1990-1995 and 1996-2001. Over the full sample period (1980-2001, third and fourth columns), emerging markets have lower correlations in their volume shocks than developed markets. Looking at the last two sub-periods, however, yields a richer picture. Whereas in the 1990-1995 sub-period the average volume shock correlations in the emerging markets is 0.18 , in the $1996-2001$ subperiod the average correlation is 0.25 , an increase of $39 \%$ percent. Meanwhile the developed markets' volume shock correlation average remains around 0.30 in both sub-periods.

\section{[Table 7 Here]}

Figure 1 provides a more detailed picture of the convergence in developed and emerging market trading volume shock correlations over time. The graph shows that the level of multimarket trading has increased dramatically in emerging markets, nearly catching up with the developed markets by 2001. Our finding of increasing multimarket trading for emerging markets over the period and higher multimarket trading among developed markets is consistent with the index- and factor-based price integration measures of Bekaert, Harvey, Lundblad, and Siegel (2011) (Figure 1) and Pukhuanthong and Roll (2009) (Figure 4). ${ }^{21}$

\section{[Figure 1 Here]}

Panel B of Table 7 compares the average volume shock correlations for the countries in our sample that have more than 10 firms each: four developed countries (Canada, France, the Netherlands, and the

\footnotetext{
${ }^{21}$ Aggregating trading volume shock correlations by industry also confirms Bekaert, Harvey, Lundblad, and Siegel's (2008) and Pukhuanthong and Roll's (2009) asset-pricing based findings of high integration in the services industry and low but increasing integration in banking; however, our analysis suggests that these industry results reflect the concentration of industry crosslistings from certain home markets rather than specific industry characteristics.
} 
U.K.) and three emerging countries (Chile, Israel and South Africa). Canada has the highest correlation of trading volume shocks, and the correlation remains constant across the sample periods. The remaining developed countries show similar levels of volume shock correlations. In contrast to Canada, however, these countries experience increases in correlations (e.g., 40\% for Netherlands and 33\% for France). Chile, surprisingly, shows levels of volume shock correlations that exceed those of the developed countries except for Canada. Israel experiences a remarkable increase in correlations of $119 \%$ across the sample periods, indicative of a greater integration in its market across time. ${ }^{22}$ South Africa shows by far the lowest level of integration and also experiences only a small increase during the 1990s.

These results are generally consistent with studies of price integration. For example, Bekaert, Harvey, Lundblad, and Siegel (2011) show a comparable ranking of countries with respect to their measure of segmentation, echo our finding that Chile's integration is comparable to many developed countries (see also Carrieri, Errunza and Hogan (2007)), and also document sharp increases in integration over the sample period. But our analysis also uncovers some notable differences. In particular, our multimarket trading measure reveals a larger gap between Canada and other developed markets and a dramatic increase in multimarket trading for Israel during the 1990s.

Our multimarket trading measure could simply be capturing the extent of price parity among crosslisting markets. To further investigate this issue we compare our volume shock correlations to the price disparity measure of Gagnon and Karolyi (2010a). ${ }^{23}$ Figure 2 presents the two measures over time for a sample of four countries (Canada, the U.K., Chile, and France) that illustrate a range of relations between price disparity and multimarket trading. There is considerable cross-sectional variation in the link between price disparities and volume shock correlations. For example, the top row shows that although

\footnotetext{
${ }^{22}$ Israel was classified as an emerging market during our entire sample period, but in 2010 was reclassified as a developed market by equity index builders such as MSCI.

${ }^{23}$ We thank Louis Gagnon and Andrew Karolyi for providing us with a daily time series of price disparities on a country level. We transform these time series into absolute values because we are not concerned about the direction of any mispricing, and we use yearly averages in our analysis.
} 
Canada and the U.K. have nearly identical levels of price disparity, ${ }^{24}$ the level of volume shock correlations is approximately twice as high in Canada as in the U.K. Although both countries are well integrated with the U.S. from a pricing perspective, they have very different levels of multimarket trading. In contrast, Chile exhibits a negative correlation between price disparities and volume correlation, while in France the price disparity stays at a relatively constant level but volume correlation nearly doubles over a 10 -year period. In general, what is consistent across countries is the evidence that countries with high levels of multimarket trading exhibit small price discrepancies. Thus to understand the extent to which traders treat different markets as one market, we need to look beyond traditional measures of price parity and also examine the extent to which trading volume shocks are correlated.

\section{[Figure 2 Here]}

\section{B. Evidence on Broadly-Defined Measures of Financial Integration}

In addition to comparing our multimarket trading measure to measures of price integration, we also relate it to measures of barriers to financial integration, namely market openness (Chinn and Ito (2008)) and capital controls (Edison and Warnock (2003)). ${ }^{25}$ Table 8 presents the results and focuses on time trends of their measures and our multimarket trading variable across the two subperiods 1990-1995 and 1996-2001. Looking at the regional trends, our study agrees with both the Chinn-Ito (2008) index and the Edison and Warnock (2003) measure: There is a significant increase in financial integration $(214.29 \%$ increase in market openness, $45.65 \%$ decrease in capital controls) across time among developing markets. Surprisingly, the Chinn-Ito index also shows a significant increase among developed markets, which our measure of multimarket trading does not find.

Some similarities can also be found on the individual country level. The Chinn-Ito index shows an

\footnotetext{
${ }^{24}$ Canada and the U.K. are also very similarly integrated with the U.S. according to other measures of market integration. For example, Bekaert, Harvey, Lundblad, and Siegel (2011) estimate segmentation measures (i.e., absolute values of the difference between industry valuation ratios) of $2.3 \%$ for Canada and $1.9 \%$ for the U.K.

${ }^{25}$ We thank Menzie Chinn, Hiro Ito, Hali Edison, and Frank Warnock for making their measures available for this analysis.
} 
increase in market openness for France, Chile, and Israel, while the Edison-Warnock proxy shows a decrease in capital controls for Chile and South Africa. These patterns are consistent with the ones we find for multimarket trading.

\section{[Table 8 Here]}

Overall, these results support the idea that price integration and multimarket trading are related but non-redundant measures of financial market integration. Our measure of volume shock correlations is also related to measures of market openness and capital controls in a consistent way. These diverse measures of financial integration overlap, but not completely; each one adds a different dimension to the broadlydefined notion of financial integration. Our measure, for example, captures not only arbitrage-based trading - key for price parity - but also other motivations for multimarket trading, including liquidity and information-based trading of investors with discretion over their trading location. By characterizing the ease of trading across markets, our measure of multimarket trading provides a different, volume-based perspective on market integration.

\section{Multimarket Trading and Post-Cross-Listing Liquidity Improvements}

In this section we explore one specific context in which our multimarket trading measure can be applied: liquidity improvements for stocks after cross-listing. In Section 5, we document that firm liquidity and the extent of multimarket trading are positively linked (that is, cross-listings which have a lot of multimarket trading also have low Amihud illiquidity measure in the cross-listing market). In this section, we examine a different aspect of this relation through an event study, looking at changes in a firm's stock liquidity before and after it cross-lists. Our conjecture is that the liquidity improvement of a firm initiating a cross listing is positively related to the extent to which investors engage in multimarket trading after the cross-listing. This positive relation may arise either because multimarket trading is easier and cheaper for more liquid domestic/cross-listed pairs of stocks or because multimarket trading magnifies the liquidity benefits of cross-listing. 
A substantial literature documents that cross listing improves a stock's liquidity (see Gagnon and Karolyi (2010b) for a comprehensive survey). We estimate the following base case panel regression to compare pre-cross-listing and post-cross-listing medians controlling for firm fixed effects, using the Amihud (2002) measure as our proxy for liquidity:

$$
\text { Amihud }_{i, t}=\alpha+\beta \times C L_{i, t}+\delta_{i}+\varepsilon_{i, t}
$$

Before a firm is cross-listed on a U.S. market we calculate the domestic Amihud measure using returns and dollar trading volume from the domestic market. After the cross-listing we estimate the Amihud measure using two different specifications: 1) the domestic Amihud measure, and 2) the volumeweighted average of the domestic and the U.S. Amihud measures. We average each measure per firm/year. $C L$ is a dummy that equals 1 after the cross-listing and 0 otherwise. We create a strongly balanced panel by using pre-and post-cross-listing median values in our empirical analysis (using five years of annual observations before and after the cross-listing event). Thus the time subscript $t$ is either pre-cross-listing or post-cross-listing for each firm.

From the cross-listing literature, we expect that $\beta$ in Equation (4) is negative because we expect illiquidity to decrease (liquidity to increase) after a firm cross-lists in the U.S. More specifically, we test whether this liquidity increase varies with the level of multimarket trading that takes place for a specific firm after the cross-listing. Thus, we estimate the above regression separately for firms with above median (High) and below median (Low) values of multimarket trading. Then we test whether $\beta_{\text {High }}$ is smaller than $\beta_{\text {Low }}$, implying a larger reduction in illiquidity (increase in liquidity) after the cross-listing when there is more multimarket trading.

Table 9 reports the results for tests of the relation between liquidity improvements and multimarket trading as well as for relations between liquidity improvements and other firm and market characteristics. We report results for both of our post-cross-listing liquidity measures: domestic Amihud (Panel A) and volume-weighted Amihud (Panel B). We are interested in whether there is a positive relation between 
multimarket trading and liquidity improvement. We thus evaluate whether our measure of multimarket trading provides a clear separation of firms that have more versus less liquidity improvement following cross-listing. We also compare the separation provided by multimarket trading to that provided by other characteristics that have been previously documented as being linked to liquidity.

\section{[Table 9 Here]}

The first two rows of Panel A of Table 9 show that stocks with high multimarket trading after crosslisting have significantly larger improvements in liquidity (that is, a larger drop in Amihud illiquidity), while stocks with low multimarket trading have no significant change in liquidity. The Chow test in the last column shows that this difference is significant, with a p-value of 5.3\%. The results appear stronger if we consider the volume-weighted Amihud measure in Panel B. In this case, the p-value of the Chow test comparing improvements in liquidity between stocks with high and low multimarket trading is $3.3 \%$. Multimarket trading clearly distinguishes between firms that increase their liquidity through cross-listing and those that do not, although these tests cannot determine cause and effect. The remaining rows of Table 9 show the results from analogous tests in which stocks are separated by other characteristics that have been linked to liquidity improvements for cross-listing firms. In contrast to the clean distinction revealed by multimarket trading, splits by other characteristics yield beta coefficients that are negative (indicating liquidity improvements, though not all significant) for both the "high" and "low" categories, and only the number of U.S. institutional investors (NumberUS) produces a Chow test that is significant at the $5 \%$ level.

Overall, the results of Table 9 provide evidence that there is a strong association between liquidity improvements and multimarket trading. This has implications not only for companies interested in crosslisting, but also for regulators and exchanges that care about market share and order flow.

\section{Conclusion}

Price and quantity are the building blocks of all theories of market interactions, yet the behavior of 
trading volume has received far less attention than the behavior of prices (Lo and Wang $(2000,2010)$ ). By examining the correlation of trading volume shocks in pairs of domestic and cross-listed stocks, we introduce a new measure of multimarket trading. Our trade-based multimarket trading measure is simple and model-free, and it complements existing price-based integration concepts.

Our results have potentially important implications for firms considering cross-listing and for firms evaluating existing cross-listings. If a firm's goal is to provide a larger global trading environment, its ability to achieve a well-integrated domestic and cross-listing market for its stock depends on the characteristics of the two markets and the specific firm. The existing literature on cross-listings (e.g., Gagnon and Karolyi (2010a)) and on market integration (e.g., Bekaert, Harvey, Lundblad and Siegel (2011)) does not address these issues.

Our results also have potential implications for the competition across countries and exchanges for order flow. An increasing number of stocks are traded on multiple markets, not only via international cross-listings but also through direct trading of the same stock on multiple venues. ${ }^{26}$ Multimarket trading is expanding rapidly in the U.S. and in Europe (e.g., O'Hara and Ye (2010) and Foucault and Menkveld (2008)). Thus all market participants, including issuers, traders, and providers of trading services, must deal with issues of multimarket trading and integration across multiple trading platforms. Our measure can be easily used to identify cross-sectional differences across firms within a country or region. Moreover, it can be used to examine whether regulatory and technological changes affect the level of multimarket trading. For example, do changes such as Reg NMS and the "trade-through rule" or the development of algorithmic trading result in greater multimarket trading? We leave investigation of such issues for future research.

\footnotetext{
${ }^{26}$ For example, the share volume of NYSE-listed equity securities executed on the NASDAQ book as a percentage of consolidated market volume was $14.2 \%$ in June 2009 . The monthly market share press release can be found at http://ir.nasdaqomx.com/releasedetail.cfm?ReleaseID=397502.
} 


\section{Appendix}

Table A1 summarizes the motivation and definition of each variable employed in the multiple regression analysis. All variables are measured annually. 


\section{References}

Admati, A. R., and P. Pfleiderer. "A theory of intraday patterns: Volume and price variability." Review of Financial Studies 1 (1988), 3-40.

Ajinkya, B., and P. Jain. "The behavior of daily stock market trading volume." Journal of Accounting and Economics, 11 (1989), 331-359.

Amihud, Y. "Illiquidity and stock returns: cross-section and time-series effects." Journal of Financial Markets, 5 (2002), 31-56.

Baruch, S.; G. A. Karolyi; and M. Lemmon. "Multimarket trading and liquidity: Theory and evidence." Journal of Finance, 62 (2007), 2169-2200.

Bekaert, G., and C. R. Harvey. "Time-varying world market integration.” Journal of Finance, 50 (1995), 403-444.

Bekaert, G.; C. R. Harvey; and R. Lumsdaine. "Dating the integration of world equity markets." Journal of Financial Economics, 65 (2002a), 203-248.

Bekaert, G.; C. R. Harvey; and R. Lumsdaine. "The dynamics of emerging markets equity flows." Journal of International Money and Finance, 15 (2002b), 1137-1187.

Bekaert, G.; C. R. Harvey; and A. Ng. "Market integration and contagion." Journal of Business, 78 (2005), 39-69.

Bekaert, G.; C. R. Harvey; C. T. Lundblad; and S. Siegel. "What segments equity markets?" Review of Financial Studies, forthcoming (2011).

Bhattacharya, U., and H. Daouk. "The world price of insider trading." Journal of Finance, 57 (2002), 75108.

Boehmer, E., and E. Kelley. "Institutional investors and the informational efficiency of prices." Review of Financial Studies, 22 (2009), 3563-3594.

Caballe, J. V., and M. Krishnan. "Imperfect competition in a multi-security market with risk neutrality." Econometrica, 62 (1994), 695-704.

Campbell, J. Y., and Y. Hamao. "Predictable stock returns in the United States and Japan: A study of long-term capital market integration." Journal of Finance, 47 (1992), 43-69.

Carrieri, F.; V. Errunza; and K. Hogan. "Characterizing world market integration through time." Journal of Financial and Quantitative Analysis, 41 (2007), 511-540.

Chakravarty, S.; C. N. Chiyachantana; and C. Jiang. "The choice of trading venue and relative price impact of institutional trading: ADRs versus the underlying securities in their local markets." Journal of Financial Research, forthcoming (2011).

Chan, J. S. P.; D. Hong; and M. G. Subrahmanyam. "A tale of two prices: Liquidity and asset prices in multiple markets.” Journal of Banking and Finance, 32 (2008), 947-960.

Chinn, M. D., and H. Ito. "A new measure of financial openness." Journal of Comparative Policy Analysis, 10 (2008), $309-322$.

Chiyachantana, C. N.; P. K. Jain; C. Jiang; and R. A. Wood. "International evidence on institutional trading behavior and price impact." Journal of Finance, 59 (2004), 869-898.

Chordia, T.; R. Roll; and A. Subrahmanyam. "Market liquidity and trading activity." Journal of Finance, 56 (2001), 501-530. 
Chowdhry, B., and V. Nanda. "Multimarket trading and market liquidity." Review of Financial Studies, 4 (1991), 483-511.

Cohen, L., and A. Frazzini. "Economic links and predictable returns." Journal of Finance, 63 (2008), 1977-2011.

Edison, H. J., and F. Warnock. "A simple measure of the intensity of capital controls." Journal of Empirical Finance, 10 (2003), 81-103.

Ellul, A.; H.S. Shin; and I. Tonks. "Opening and closing the market: Evidence from the London Stock Exchange.” Journal of Financial and Quantitative Analysis, 40 (2005), 779-801.

Feng, L., and M. S. Seasholes. "Correlated trading and location.” Journal of Finance, 59 (2004), 21172144.

Foucault, T., and A. Menkveld. "Competition for order flow and smart order routing systems." Journal of Finance, 63 (2008), 119-158.

Gagnon, L., and G. A. Karolyi. "Information, trading volume, and international stock return comovements: Evidence from cross-listed stocks." Journal of Financial and Quantitative Analysis, 44 (2009), 953-986.

Gagnon, L., and G. A. Karolyi. "Multimarket trading and arbitrage." Journal of Financial Economics, 97 (2010a), 53-80.

Gagnon, L., and G. A. Karolyi. "Do International Cross-Listings Still Matter?" in Evidence on Financial Globalization and Crises, Thorsten Beck, Sergio Schmukler, and Stijn Claessens (Editors), Elsevier North-Holland Publishers, forthcoming (2010b).

Greene, W. H. “Econometric Analysis.” Prentice Hall, $5^{\text {th }}$ Edition (2003).

Halling, M.; M. Pagano; O. Randl; and J. Zechner. "Where is the market? Evidence from cross-listings in the United States.” Review of Financial Studies, 21 (2008), 725-761.

Hupperets, E., and A. Menkveld. "Intraday analysis of market integration: Dutch blue chips traded in Amsterdam and New York.” Journal of Financial Markets, 5 (2002), 57-82.

Jain, P. "Financial market design and the equity premium: Electronic versus floor trading." Journal of Finance, 60 (2005), 2955-2985.

Jorion, P., and E. Schwartz. "Integration vs. Segmentation in the Canadian stock market." Journal of Finance, 41 (1986), 603-614.

JPMorgan. "Buy-side survey: ADR investigation.” www.adr.com, 15 pages (2003).

Karolyi, G. A.; K. Lee; and M. A. Van Dijk. "Understanding commonality in liquidity around the world." Journal of Financial Economics, forthcoming (2011).

Kim, M.; A. C. Szakmary; and I. Mathur. "Price transmission dynamics between ADRs and their underlying foreign securities.” Journal of Banking and Finance, 24 (2000), 1359-1382.

King, M., and S. Wadhwani. "Transmission of volatility between stock markets." Review of Financial Studies, 3 (1990), 5-33.

Kodres, L. E., and M., Pritsker. "A rational expectations model of financial contagion." Journal of Finance, 57 (2002), 769-799.

Kyle, A., and W. Xiong. "Contagion as a wealth effect." Journal of Finance, 56 (2001), 1401-1440. 
Lo, A. W., and J. Wang. "Trading volume: Definitions, data analysis, and implications for portfolio theory." Review of Financial Studies, 13 (2000), 257-300.

Lo, A. W., and J. Wang. "Stock market trading volume." in The Handbook of Financial Econometrics, Y. Ait-Sahalia and L. Hansen editors, Volume 2, North-Holland (2010).

Menkveld, A. "Splitting orders in overlapping markets: A study of cross-listed stocks." Journal of Financial Intermediation, 17 (2008), 145-174.

Mittoo, U. R. “Additional Evidence on Integration in the Canadian stock market.” Journal of Finance, 47 (1992), 2035-2054.

Moulton, P., and L. Wei. "A tale of two time zones: The impact of substitutes on cross-listed stock liquidity.” Journal of Financial Markets, 12 (2009), 570-591.

Meulbroek, L. "An empirical analysis of insider trading and the stock market." Journal of Finance, 47 (1990), 1661-1699.

O'Hara, M., and M. Ye. "Is market fragmentation harming market quality?" Journal of Financial Economics, forthcoming (2010).

Pagano, M. "Trading volume and asset liquidity." Quarterly Journal of Economics, 104 (1989), 255-274.

Pagano, M.; A. Röell; and J. Zechner. "The geography of equity listing: Why do companies list abroad?" Journal of Finance, 57 (2002), 2651-2694.

Pasquariello, P. "Information heterogeneity and financial contagion." Review of Financial Studies, 20 (2007), 391-426.

Pasquariello, P., and C. Vega. "Strategic cross-trading in the U.S. stock market." Working paper (2010).

Petersen, M. "Estimating standard errors in finance panel data sets: Comparing approaches." Review of Financial Studies, 22 (2009), 435-480.

Pukthuanthong, K., and R. Roll. "Global market integration: An alternative measure and its application." Journal of Financial Economics, 94 (2009), 214-232.

Sanders, R., and J. Zdanowicz. "Target firm abnormal returns and trading volume around the initiation of change in control transactions." Journal of Financial and Quantitative Analysis, 27 (1992),109-129.

Sexton, R. J.; C. L. Kling; and H. F. Carman. "Market integration, efficiency of arbitrage, and imperfect competition: Methodology and application to U.S. celery." American Journal of Agricultural Economics, 73 (1991), 568-580.

Thompson, S. "Simple formulas for standard errors that cluster by both firm and time." Journal of Financial Economics, 99 (2011), 1-10.

Werner, I. M., and A. W. Kleidon. "U.K. and U.S. trading of British cross-listed stocks: An intraday analysis of market integration." Review of Financial Studies, 9 (1996), 619-664.

Yuan, K. "Asymmetric price movement and the borrowing constraint: a REE model of crises, contagion, and confusion." Journal of Finance, 60 (2005), 379-411. 
Table 1. Sample Descriptive Statistics

This table presents descriptive statistics per country for the sample of 361 firms cross-listed in the U.S. over the period 1980-2001; not all firms are present in the sample in all years. Mean values are reported in the table, with means calculated in two steps: first, by averaging the variables over time (using daily observations for trading volumes, annual observations for remaining variables) for each firm; second, by averaging firm means within each country.

\begin{tabular}{|c|c|c|c|c|c|c|}
\hline $\begin{array}{l}\text { Home } \\
\text { Market }\end{array}$ & $\begin{array}{l}\text { Overlap } \\
\text { in } \\
\text { Hours } \\
\end{array}$ & $\begin{array}{c}\text { Number of } \\
\text { Firms }\end{array}$ & $\begin{array}{c}\text { Domestic Trading } \\
\text { Volume } \\
\text { in USD } \\
\end{array}$ & $\begin{array}{c}\text { Cross-listed Trading } \\
\text { Volume } \\
\text { in USD } \\
\end{array}$ & $\begin{array}{l}\text { Foreign } \\
\text { Sales } \\
\text { in \% } \\
\end{array}$ & $\begin{array}{l}\text { Assets } \\
\text { in USD } \\
\text { million }\end{array}$ \\
\hline Argentina & 6.00 & 5 & 1,157 & 10,859 & 3 & 6,008 \\
\hline Belgium & 2.00 & 1 & 18,655 & 415 & $\mathrm{n} / \mathrm{a}$ & 9,378 \\
\hline Brazil & 6.50 & 2 & $4,601,056$ & 99,542 & 0 & 11,160 \\
\hline Canada & 6.50 & 186 & 3,237 & 2,589 & 50 & 4,718 \\
\hline Chile & 6.50 & 12 & 448 & 972 & 27 & 3,225 \\
\hline Colombia & 2.50 & 1 & 55 & 267 & $\mathrm{n} / \mathrm{a}$ & 3,343 \\
\hline Denmark & 1.50 & 2 & 7,560 & 973 & 59 & 2,385 \\
\hline Finland & 1.83 & 2 & 171,978 & 170,942 & 50 & 10,260 \\
\hline France & 2.00 & 14 & 41,772 & 7,361 & 61 & 40,610 \\
\hline Germany & 4.50 & 6 & 245,103 & 7,319 & 45 & 43,890 \\
\hline Ireland & 2.00 & 4 & 4,589 & 26,452 & 73 & 4,803 \\
\hline Israel & 0.50 & 15 & 944 & 4,164 & 52 & 1,075 \\
\hline Italy & 2.00 & 5 & 67,699 & 1,281 & 52 & 15,670 \\
\hline Mexico & 6.50 & 6 & 1,195 & 1,784 & 22 & 1,956 \\
\hline Netherlands & 2.00 & 17 & 50,775 & 14,103 & 64 & 38,950 \\
\hline Norway & 1.00 & 4 & 8,389 & 2,609 & 66 & 8,308 \\
\hline Peru & 4.00 & 3 & 895 & 2,477 & 8 & 4,254 \\
\hline Portugal & 3.00 & 1 & 14,926 & 392 & $\mathrm{n} / \mathrm{a}$ & 13,710 \\
\hline South Africa & 0.50 & 13 & 4,029 & 1,195 & 3 & 1,572 \\
\hline Spain & 2.00 & 3 & 43,853 & 3,938 & 26 & 55,480 \\
\hline Sweden & 2.00 & 7 & 34,155 & 16,214 & 81 & 7,467 \\
\hline Switzerland & 2.00 & 2 & 3,269 & 407 & 76 & 933 \\
\hline U.K. & 2.00 & 48 & 40,028 & 6,124 & 59 & 24,150 \\
\hline Venezuela & 4.50 & 2 & 217 & 684 & 14 & 424 \\
\hline Total & 4.52 & 361 & 40,970 & 5,606 & 51 & 12,050 \\
\hline
\end{tabular}




\section{Table 2. Summary of VAR Results}

This table reports average statistics for the VAR estimated for the domestic and the crosslisted trading volume of each firm each year. The dependent variables are the log of the ratio of day $t$ to day $t-1$ domestic dollar trading volume (DomesticVolChg) and the log of the ratio of day $t$ to day $t-1$ foreign dollar trading volume (CrossListVolChg). We report means and standard deviations of the coefficients and of the individual p-values of the coefficients. For brevity we report only the first lags. The number of lags is determined per firm and per year using the Akaike Information Criterion (AIC). VARs also include the following exogenous variables: stock returns, foreign exchange returns of the domestic currency with respect to the USD, the $\log$ of the ratio of day $t$ to day $t-1$ domestic total dollar trading volume and the log of the ratio of day $t$ to day $t-1$ foreign total dollar trading volume. For brevity we do not report the coefficients of these exogenous variables.

\begin{tabular}{|c|c|c|c|c|c|}
\hline & & \multicolumn{4}{|c|}{ Trading Volume Changes } \\
\hline & & \multicolumn{2}{|c|}{ DomesticVolChg $_{t}$} & \multicolumn{2}{|c|}{ CrossListVolChg $_{t}$} \\
\hline & & Mean & $\mathrm{SD}$ & Mean & SD \\
\hline Coeff & $\frac{i}{\frac{I}{0}}$ & -0.51 & 0.16 & 0.05 & 0.21 \\
\hline P-Value & $\begin{array}{l}\stackrel{\overrightarrow{\tilde{O}}}{0} \\
\stackrel{0}{0} \\
\stackrel{0}{0}\end{array}$ & 0.01 & 0.06 & 0.42 & 0.31 \\
\hline Coeff & $\begin{array}{l}\frac{1}{00} \\
\frac{0}{0}\end{array}$ & 0.07 & 0.13 & -0.56 & 0.14 \\
\hline P-Value & $\begin{array}{l}\vec{v} \\
0 \\
0 \\
0\end{array}$ & 0.37 & 0.31 & 0.01 & 0.05 \\
\hline R-Square & & 0.39 & 0.11 & 0.34 & 0.09 \\
\hline
\end{tabular}




\section{Table 3. Correlation of Residuals by Overlap of Trading Hours}

This table reports average correlations and standard deviations across markets with different trading-hour overlaps (in percent of the domestic trading hours). The correlations are yearly correlations calculated from the daily residuals (shocks) of VARs. We report correlations based on VARs that use the $\log$ of the ratio of day $t$ to day $t-1$ domestic and foreign trading volume (CorrVolChange) as dependent variables. VARs also include the following exogenous variables: stock returns, foreign exchange returns of the local currency on the domestic market with respect to the USD, the $\log$ of the ratio of day $t$ to day $t-1$ domestic total dollar trading volume and the $\log$ of the ratio of day $t$ to day $t-1$ foreign total dollar trading volume. The column "Sig 5\%" reports the percentage of trading volume shock correlations that are significantly different from zero at the $5 \%$ level. There are no market pairs with trading hours overlap between $50 \%$ and $75 \%$.

\begin{tabular}{ccccc}
\hline $\begin{array}{c}\text { Percentage } \\
\text { Overlap }\end{array}$ & Number of & \multicolumn{3}{c}{ CorrVolChange } \\
Domestic Countries & Mean & SD & Sig 5\% \\
\hline Less than 25\% & 5 & 0.15 & 0.13 & $75 \%$ \\
$25 \%$ to less than 50\% & 11 & 0.18 & 0.13 & $83 \%$ \\
More than 75\% & 8 & 0.38 & 0.17 & $94 \%$ \\
\hline Total & 24 & 0.28 & 0.18 & $88 \%$ \\
\hline
\end{tabular}




\section{Table 4. Explanatory Variables and Predicted Signs}

This table summarizes the expected influence of each proxy for market- or firm-level barriers and benefits on trading volume shock correlations.

Explanatory variable (abbreviation)

Predicted effect on trading volume shock correlation

\section{Market-Level}

Trading hours overlap (Overlap)

$+$

Trading cost difference (TCostDiff)

Trading cost sum (TCostComb)

Dollar trading volume on cross-listing/domestic market, measured as absolute deviation from one (MarketVolumeIndex)

Total dollar trading volume on cross-listing and domestic market (MarketVolumeComb)

Protection against insider trading in the domestic market (ITProtect)

Short sales permitted (ShortSale)

Market design different (MktDesignDiff)

Firm-Level

Domestic and US Amihud illiquidity measures (DomesticAmihud, USAmihud)

Firm's dollar trading volume on cross-listing/domestic market, measured as absolute deviation from one (FirmVolumeIndex)

Stock return correlation to cross-listing market's return (CLCorr)

Baruch-Karolyi-Lemmon relative information measure (BKLMeasure)

Percentage of shares held by U.S. institutions (SharesUS)

Number of U.S. institutions invested in the firm (NumberUS)

Fraction of firm's sales from foreign markets (ForSales)

Technology sector (TechSec)

Control Variables

Firm size (Size)

Idiosyncratic volatility (StockVolatility)

Absolute yearly stock return (Return)

Years since first cross-listed (CLAge) 


\section{Table 5. Correlation Matrix}

This table summarizes correlations between volume shock correlations and potential explanatory variables. CorrVolChange is the correlation of trading volume shocks from the VAR using daily trading volume changes in the domestic and the cross-listing markets. Overlap is percentage of domestic market trading hours that overlap with cross-listing market trading hours; TCostDiff is an indicator variable taking the value of one if the absolute difference between total trading costs on the domestic and cross-listing markets is above the median value of market pairs, else zero; TCostComb is the sum of the total trading costs for domestic and cross-listing markets; MarketVolumeIndex is the log of the absolute difference between one and the ratio of total dollar trading volume (for all stocks) on the domestic and cross-listing markets; MarketVolumeComb is the sum of total dollar trading volume on the domestic and cross-listing markets; ITProtect is an indicator variable that equals one in year $t$ if insider trading laws have been enforced in the home market during or before year $t$, else zero; ShortSale is an indicator variable equal to one in year $t$ if short sales are permitted in that market that year, else zero; MktDesignDiff is an indicator variable that equals one in year $t$ if electronic trading has been introduced in either the domestic market or the cross-listing market, but not both, before year $t$, else zero; DomesticAmihud (USAmihud) is the ratio of the absolute stock return in the domestic (US) market to trading volume in the domestic (US) market; FirmVolumeIndex is the log of the absolute difference between one and the ratio of the firm's dollar trading volume on the cross-listing market to the domestic market; CLCorr is the stock return correlation to the cross-listing market's return; BKL Measure is the measure of relative information revelation from Baruch, Karolyi, and Lemmon (2007); SharesUS is the percentage of shares held by U.S. institutions; NumberUS is the number of U.S. institutions invested in a firm; ForSales is the fraction of foreign sales; TechSec is an indicator variable that equals one for technology-oriented companies, else zero; Size is total assets of the firm; StockVolatility is the volatility of the residuals in a regression in which stock returns are regressed on 
returns of the cross-listing and the domestic market indices; and Return is the stock's home-currency log price change over the year. Bold correlations indicate correlations that are significantly different from zero at the $5 \%$ level. 


\begin{tabular}{|c|c|c|c|c|c|c|c|c|c|c|c|c|c|c|c|c|c|c|c|c|c|}
\hline & 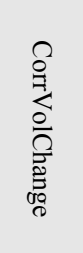 & 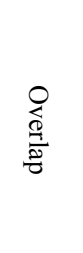 & 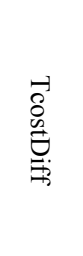 & $\begin{array}{l}\overrightarrow{\widehat{\delta}} \\
\stackrel{0}{0} \\
\hat{ᄋ} \\
\hat{\sigma}\end{array}$ & 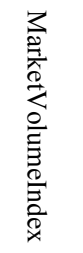 & 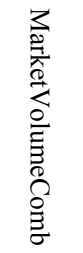 & $\begin{array}{l}\vec{\exists} \\
\overrightarrow{0} \\
\stackrel{0}{0} \\
\stackrel{\nexists}{\circledR}\end{array}$ & 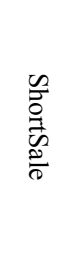 & 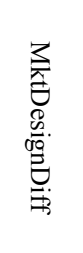 & 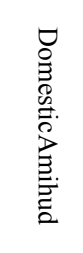 & 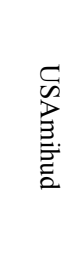 & 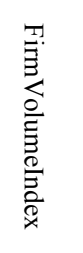 & $\stackrel{\wp}{\wp}$ & 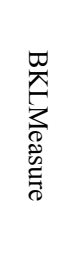 & 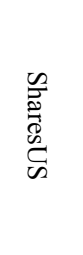 & 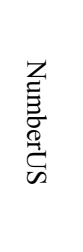 & 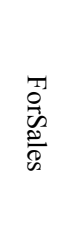 & 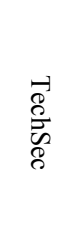 & స్. & 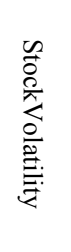 & 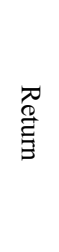 \\
\hline Overlap & 0.56 & 1.00 & & & & & & & & & & & & & & & & & & & \\
\hline TCostDiff & -0.14 & -0.16 & 1.00 & & & & & & & & & & & & & & & & & & \\
\hline TCostComb & -0.08 & -0.04 & 0.89 & 1.00 & & & & & & & & & & & & & & & & & \\
\hline MarketVolumeIndex & -0.40 & -0.59 & 0.09 & -0.09 & 1.00 & & & & & & & & & & & & & & & & \\
\hline MarketVolumeComb & 0.10 & 0.05 & -0.41 & -0.63 & 0.11 & 1.00 & & & & & & & & & & & & & & & \\
\hline ITProtect & 0.23 & 0.31 & 0.00 & -0.05 & -0.30 & 0.23 & 1.00 & & & & & & & & & & & & & & \\
\hline ShortSale & 0.10 & 0.06 & -0.25 & -0.19 & -0.59 & -0.01 & 0.13 & 1.00 & & & & & & & & & & & & & \\
\hline MktDesignDiff & -0.15 & 0.00 & -0.05 & 0.01 & 0.10 & -0.06 & -0.10 & -0.12 & 1.00 & & & & & & & & & & & & \\
\hline DomesticAmihud & -0.03 & 0.08 & -0.02 & -0.03 & -0.04 & 0.01 & 0.03 & 0.02 & -0.07 & 1.00 & & & & & & & & & & & \\
\hline USAmihud & -0.01 & 0.06 & -0.01 & -0.00 & -0.05 & 0.01 & 0.03 & 0.02 & -0.06 & 0.23 & 1.00 & & & & & & & & & & \\
\hline FirmVolumeIndex & -0.09 & 0.10 & -0.04 & -0.06 & 0.07 & 0.09 & 0.02 & -0.13 & -0.02 & 0.22 & -0.02 & 1.00 & & & & & & & & & \\
\hline CLCorr & 0.02 & -0.10 & -0.01 & -0.08 & 0.14 & 0.03 & 0.12 & -0.04 & 0.00 & -0.09 & -0.06 & 0.01 & 1.00 & & & & & & & & \\
\hline BKLMeasure & 0.14 & -0.01 & -0.08 & -0.10 & -0.05 & 0.04 & 0.02 & 0.10 & -0.12 & -0.02 & -0.04 & 0.08 & 0.28 & 1.00 & & & & & & & \\
\hline SharesUS & 0.16 & 0.07 & 0.07 & 0.01 & -0.06 & 0.09 & 0.09 & 0.02 & 0.07 & -0.05 & -0.04 & 0.03 & 0.15 & 0.12 & 1.00 & & & & & & \\
\hline NumberUS & 0.08 & -0.16 & 0.07 & 0.00 & 0.09 & 0.05 & 0.06 & 0.03 & 0.09 & -0.03 & -0.04 & -0.04 & 0.24 & 0.06 & 0.48 & 1.00 & & & & & \\
\hline ForSales & 0.09 & -0.09 & 0.06 & 0.02 & 0.01 & 0.04 & 0.19 & 0.14 & -0.09 & 0.04 & -0.04 & -0.01 & 0.11 & 0.07 & 0.14 & 0.18 & 1.00 & & & & \\
\hline TechSec & 0.15 & 0.01 & 0.03 & 0.03 & -0.03 & 0.07 & 0.11 & -0.01 & -0.18 & 0.00 & -0.03 & 0.12 & 0.17 & 0.07 & -0.01 & 0.11 & -0.04 & 1.00 & & & \\
\hline Size & -0.32 & -0.41 & 0.17 & 0.15 & 0.29 & -0.15 & -0.12 & -0.03 & 0.23 & -0.10 & -0.16 & -0.16 & 0.33 & -0.07 & 0.08 & 0.35 & 0.10 & -0.11 & 1.00 & & \\
\hline StockVolatility & 0.14 & 0.13 & -0.06 & -0.05 & -0.11 & 0.01 & 0.03 & 0.04 & -0.18 & 0.14 & 0.07 & 0.08 & -0.20 & -0.03 & -0.08 & -0.12 & -0.02 & 0.01 & -0.27 & 1.00 & \\
\hline Return & 0.19 & 0.12 & -0.11 & -0.12 & -0.09 & 0.18 & 0.07 & 0.06 & -0.19 & 0.07 & 0.05 & 0.09 & -0.09 & 0.04 & -0.03 & -0.10 & 0.02 & 0.10 & -0.30 & 0.21 & 1.00 \\
\hline
\end{tabular}




\section{Table 6. Volume Shock Correlations and Multimarket Trading Barriers and Benefits}

This table presents results from regressing firm/year correlations of trading volume shocks on proxies for multimarket trading barriers and benefits. The dependent variable is the correlation of trading volume shocks from the VAR using daily trading volume changes in the domestic and cross-listing markets (CorrVolChange). Overlap is percentage of domestic market trading hours that overlap with cross-listing market trading hours; TCostDiff is an indicator variable taking the value of one if the absolute difference between total trading costs on the domestic and cross-listing markets is above the median value of market pairs, else zero; TCostComb is the sum of the total trading costs for domestic and cross-listing markets; MarketVolumeIndex is the log of the absolute difference between one and the ratio of total dollar trading volume (for all stocks) on the domestic and cross-listing markets; MarketVolumeComb is the sum of total dollar trading volume on the domestic and cross-listing markets; ITProtect is an indicator variable that equals one in year $t$ if insider trading laws have been enforced in the home market during or before year $t$, else zero; ShortSale is an indicator variable equal to one in year $t$ if short sales are permitted in that market that year, else zero; MktDesignDiff is an indicator variable that equals one in year $t$ if electronic trading has been introduced in either the domestic market or the cross-listing market, but not both, before year $t$, else zero; DomesticAmihud (USAmihud) is the ratio of the absolute stock return in the domestic (US) market to trading volume in the domestic (US) market; FirmVolumeIndex is the log of the absolute difference between one and the ratio of the firm's dollar trading volume on the crosslisting market to the domestic market; CLCorr is the stock return correlation to the cross-listing market's return; BKL Measure is the measure of relative information revelation from Baruch, Karolyi, and Lemmon (2007); SharesUS is the percentage of shares held by U.S. institutions; NumberUS is the number of U.S. institutions invested in a firm; ForSales is the fraction of foreign sales; TechSec is an indicator variable that equals one for technology-oriented 
companies, else zero; Size is total assets of the firm; StockVolatility is the volatility of the residuals in a regression in which stock returns are regressed on returns of the cross-listing and the domestic market indices; Return is the stock's home-currency log price change over the year; and CLAge is the number of years since the firm was first cross-listed.

All variables except indicator variables are normalized by their standard deviations. All specifications include calendar-year fixed effects, not reported, and $t$-statistics (in parentheses) are based on robust standard errors. 


\begin{tabular}{|c|c|c|c|c|c|}
\hline & 1 & 2 & 3 & Spec. 4 & 5 \\
\hline & 0.06 & & & 0.08 & 0.08 \\
\hline Overlap & $(5.87)$ & & & $(7.77)$ & $(8.78)$ \\
\hline & -0.01 & & & -0.02 & -0.03 \\
\hline TC & $(-0.43)$ & & & $(-0.84)$ & $(-1.45)$ \\
\hline TcostComb & -0.01 & & & 0.00 & 0.00 \\
\hline ne & $-(-0.83)$ & & & $(-0.3 \underline{5})$ & $(\underline{0 .} 48)_{-}$ \\
\hline MarketVolumeIndex & $\begin{array}{c}-0.02 \\
(-1.64)\end{array}$ & & & $\begin{array}{l}-0.02 \\
(-1.19)\end{array}$ & $\begin{array}{c}-0.02 \\
(-1.62)\end{array}$ \\
\hline MarketVolumeComb & $\begin{array}{r}0.15 \\
-(1.71)\end{array}$ & & & $\begin{array}{l}-0.01 \\
(-0.08)\end{array}$ & $\begin{array}{l}-0.12 \\
(-1.42)\end{array}$ \\
\hline ITProtect & $\begin{array}{c}0.01 \\
(1.11)\end{array}$ & & & $\begin{array}{l}0.01 \\
(1.13)\end{array}$ & $\begin{array}{c}0.01 \\
(0.78)\end{array}$ \\
\hline ShortSale & $\begin{array}{l}0.05 \\
(174)\end{array}$ & & & 0.05 & $\begin{array}{l}0.06 \\
(239)\end{array}$ \\
\hline MktDesignDiff & -0.02 & & & $\begin{array}{l}-0.03 \\
(-2.95)\end{array}$ & -0.01 \\
\hline----------- & $(-2.4-2$ & $-\overline{-0.0 \overline{2}}$ & 0.00 & $\begin{array}{l}-(-2.95) \\
0.00\end{array}$ & $=0$. \\
\hline $\begin{array}{l}\text { DomesticAmihud } \\
\end{array}$ & & $(-1.26)$ & $(-1.32)$ & $(0.19)_{-}$ & $(-0.77)$ \\
\hline USAmihud & & $\begin{array}{c}-0.02 \\
(-3.50)\end{array}$ & $\begin{array}{l}-0.02 \\
(-6.46)\end{array}$ & $\begin{array}{c}-0.02 \\
(-6.49)\end{array}$ & $\begin{array}{c}-0.02 \\
(-5.86)\end{array}$ \\
\hline FirmVolumeIndex & & $(-4.64)$ & $\begin{array}{l}-0.03 \\
(-5.36)\end{array}$ & $(-5.61)$ & $\begin{array}{l}-0.03 \\
(-6.13)\end{array}$ \\
\hline CLCorr & & 0.01 & $(1.13)$ & $\begin{array}{l}0.00 \\
(0.57)\end{array}$ & $\begin{array}{l}0.00 \\
(0.74)\end{array}$ \\
\hline BKLMeasure & & $\begin{array}{l}0.01 \\
(2.29)\end{array}$ & $\begin{array}{l}0.01 \\
(1.60)\end{array}$ & $\begin{array}{l}0.01 \\
(1.98)\end{array}$ & $\begin{array}{l}0.01 \\
(1.88)\end{array}$ \\
\hline SharesUS & & $\begin{array}{c}0.01 \\
(1.15)\end{array}$ & $\begin{array}{l}0.01 \\
(1.43)\end{array}$ & $\begin{array}{c}0.01 \\
(1.35)\end{array}$ & $\begin{array}{l}0.00 \\
(0.45)\end{array}$ \\
\hline NumberUS & & 0.03 & 0.03 & 0.03 & 0.03 \\
\hline ForSales & & $\begin{array}{l}(3.29) \\
0.01 \\
(1.12)\end{array}$ & $(4.26)$ & $(4.30)$ & $(\underline{5} .65)_{-}$ \\
\hline TechSec & & 0.04 & $0.05^{-}$ & $\overline{0.0 \overline{6}}$ & $0 . \overline{0} \overline{-}^{-}$ \\
\hline$-\ldots-$ & & _(1. & $(2.65)$ & $(3.46)_{-}$ & $(2.81)$ \\
\hline Size & & $\begin{array}{c}-0.05 \\
(-5.20)\end{array}$ & $\begin{array}{c}-0.05 \\
(-6.89) \\
\end{array}$ & $\begin{array}{c}-0.02 \\
(-2.78)\end{array}$ & $\begin{array}{c}-0.02 \\
(-3.52)\end{array}$ \\
\hline StockVolat & & $\begin{array}{c}0.09 \\
(3.45) \\
\end{array}$ & $\begin{array}{c}0.02 \\
-(1.58)\end{array}$ & $\begin{array}{c}0.01 \\
(1.04)\end{array}$ & $\begin{array}{c}0.01 \\
(1.37)\end{array}$ \\
\hline Return & & $\begin{array}{c}0.01 \\
(3.23) \\
\end{array}$ & $\begin{array}{c}0.01 \\
(3.36) \\
\end{array}$ & $\begin{array}{l}0.01 \\
(3.13)\end{array}$ & $\begin{array}{c}0.02 \\
(3.82)\end{array}$ \\
\hline CLAge & & $\begin{array}{l}0.02 \\
(1.69)\end{array}$ & $\begin{array}{c}0.01 \\
(0.76) \\
\end{array}$ & $\begin{array}{c}0.01 \\
(2.08)\end{array}$ & $\begin{array}{l}0.01 \\
(1.43)\end{array}$ \\
\hline Lagged D & & & & & $\begin{array}{c}0.22 \\
(7.38)\end{array}$ \\
\hline Constant & $\begin{array}{c}-2.56 \\
(-1.59) \\
\end{array}$ & $\begin{array}{c}0.35 \\
(7.46) \\
\end{array}$ & $\begin{array}{c}0.41 \\
(12.48)\end{array}$ & $\begin{array}{c}0.29 \\
(0.16) \\
\end{array}$ & $\begin{array}{r}2.29 \\
(1.47) \\
\end{array}$ \\
\hline $\mathrm{R}-\mathrm{Sc}$ & $35 \%$ & $32 \%$ & $25 \%$ & $49 \%$ & $59 \%$ \\
\hline Firm & 292 & 212 & 263 & 239 & 222 \\
\hline Firm Years & 1959 & 1131 & 1584 & 1467 & 1282 \\
\hline
\end{tabular}




\section{Table 7. Volume Shock Correlations Across Markets}

This table summarizes trading volume shock correlations (based on the VARs of trading volume changes, CorrVolChange) for emerging versus developed countries in Panel A, and for the countries with the largest samples of cross-listed stocks (more than 10 stocks) in Panel B. In each case, we report means and standard deviations for the full period 1980-2001 and for three sub-periods, 1980-1989 (most developed market data available, no emerging market data available), 1990-1995, and 1996-2001. The reported mean (standard deviation) is the time-series mean (standard deviation) of the equal-weighted average volume shock correlations per country or group of countries per year. The last column reports the percentage change in trading volume shock correlations across the 1990-1995 and 1996-2001 sub-periods. Significance tests compare the given values to zero, with $* *$ and $*$ indicating significance at the $1 \%$ and $5 \%$ levels, respectively. 


\begin{tabular}{|c|c|c|c|c|c|c|c|c|c|c|}
\hline & \multirow[b]{2}{*}{ Firm Years } & \multicolumn{2}{|c|}{$1980-2001$} & \multicolumn{2}{|c|}{$1980-1989$} & \multicolumn{2}{|c|}{$1990-1995$} & \multicolumn{2}{|c|}{ 1996-2001 } & \multirow[b]{2}{*}{$\begin{array}{l}\text { Change in Correlation: } \\
\text { 1990-1995 vs. } 1996-2001\end{array}$} \\
\hline & & Mean & $\mathrm{SD}$ & Mean & $\mathrm{SD}$ & Mean & $\mathrm{SD}$ & Mean & $\mathrm{SD}$ & \\
\hline \multicolumn{11}{|c|}{ Panel A: Emerging vs. Developed Countries } \\
\hline Emerging & 245 & $0.23 * *$ & 0.17 & & & $0.18^{* *}$ & 0.17 & $0.25^{* *}$ & 0.16 & $+38.80 \% * *$ \\
\hline Developed & 1855 & $0.29 * *$ & 0.18 & $0.29 * *$ & 0.18 & $0.30 * *$ & 0.20 & $0.29 * *$ & 0.18 & $-3.02 \%$ \\
\hline \multicolumn{11}{|c|}{ Panel B: Individual Countries } \\
\hline Canada & 958 & $0.39 * *$ & 0.17 & $0.36^{* *}$ & 0.17 & $0.40 * *$ & 0.18 & $0.40 * *$ & 0.17 & $-1.74 \%$ \\
\hline France & 77 & $0.20 * *$ & 0.14 & & & $0.16^{* *}$ & 0.10 & $0.21 * *$ & 0.14 & $+32.90 \%$ \\
\hline Netherlands & 149 & $0.20 * *$ & 0.12 & $0.19 * *$ & 0.15 & $0.16^{* *}$ & 0.12 & $0.22 * *$ & 0.11 & $+40.13 \% * *$ \\
\hline U.K. & 407 & $0.19^{* *}$ & 0.12 & $0.24 * *$ & 0.14 & $0.17 * *$ & 0.11 & $0.19^{* *}$ & 0.12 & $+10.71 \%$ \\
\hline Chile & 70 & $0.28 * *$ & 0.13 & & & $0.25 * *$ & 0.16 & $0.29 * *$ & 0.12 & $+15.42 \%$ \\
\hline Israel & 46 & $0.18 * *$ & 0.09 & & & 0.08 & 0.15 & $0.18^{* *}$ & 0.08 & $+119.28 \% *$ \\
\hline South Africa & 84 & $0.12 * *$ & 0.13 & & & $0.11^{* *}$ & 0.14 & $0.12^{* *}$ & 0.12 & $+8.77 \%$ \\
\hline All Firms & 2100 & $0.28 * * *$ & 0.18 & $0.29 * * *$ & 0.18 & $0.28 * * *$ & 0.20 & $0.28 * * *$ & 0.18 & $-0.01 \%$ \\
\hline
\end{tabular}




\section{Table 8. Volume Shock Correlations vs. Measures of Openness}

The first column repeats the last column from the previous table. The remainder of the table shows similar statistics for the Chinn-Ito Index of openness and the Edison-Warnock measure of capital controls. The Edison-Warnock measure of capital controls is available for emerging markets only. Significance tests compare the given values to zero, with ** and * indicating significance at the $1 \%$ and $5 \%$ levels, respectively.

\begin{tabular}{|c|c|c|c|c|c|c|c|}
\hline & \multirow{2}{*}{$\begin{array}{c}\text { Volume Shock Correlations } \\
\text { Change: } 1990-1995 \text { vs. } 1996-2001\end{array}$} & \multicolumn{3}{|c|}{ Chinn-Ito Index } & \multicolumn{3}{|c|}{ Edison-Warnock } \\
\hline & & 1990-1995 & $1996-2001$ & Change & 1990-1995 & $1996-2001$ & Change \\
\hline Emerging & $+38.80 \% * *$ & -0.28 & 0.32 & $214.29 \% * *$ & 0.46 & 0.25 & $-45.65 \% * *$ \\
\hline Developed & $-3.02 \%$ & 1.78 & 2.34 & $31.46 \% * *$ & & & \\
\hline Canada & $-1.74 \%$ & 2.48 & 2.48 & $0.00 \%$ & & & \\
\hline France & $+32.90 \%$ & 1.41 & 2.48 & $75.89 \% * *$ & & & \\
\hline Netherlands & $+40.13 \% * *$ & 2.48 & 2.48 & $0.00 \%$ & & & \\
\hline U.K. & $+10.71 \%$ & 2.48 & 2.48 & $0.00 \%$ & & & \\
\hline Chile & $+15.42 \%$ & -1.46 & 0.79 & $154.11 \% * *$ & 0.35 & 0.14 & $-60.00 \% *$ \\
\hline Israel & $+119.28 \% *$ & -0.62 & 1.32 & $312.90 \% * *$ & & 0.01 & \\
\hline South Africa & $+8.77 \%$ & -1.09 & -1.15 & $-5.50 \%$ & 0.02 & -0.01 & $-150.00 \% * *$ \\
\hline All & $-0.01 \%$ & 1.07 & 1.67 & $56.07 \% * *$ & & & \\
\hline
\end{tabular}




\section{Table 9. $\quad$ Liquidity Changes Around Cross-Listing Events}

The table reports estimates of the effect of cross-listings on the domestic Amihud measure (Panel A) and a volume-weighted Amihud measure (Panel B). The Volume-weighted Amihud measure weights the post-cross-listing domestic and US Amihud measures by volume in each market. The table reports coefficient estimates (Beta) of the panel regression specified in equation 4 for subsets of firms which are either above the median (High) or below the median (Low) with respect to each of the following characteristic: Multimarket Trading is the correlation of trading volume shocks from the VAR using daily trading volume changes in the domestic and the cross-listing markets; FirmVolumeIndex is the log of the absolute difference between one and the ratio of the firm's dollar trading volume on the cross-listing market to the domestic market; Size is the total assets of the firm; SharesUS is the percentage of shares held by U.S. institutions; NumberUS is the number of U.S. institutions invested in a firm; BKLMeasure is the measure of relative information revelation from Baruch, Karolyi, and Lemmon (2007); and MarketVolumeIndex is the sum of total dollar trading volume on the domestic and cross-listing markets. The last column contains the p-value of a Chow test that evaluates the null hypothesis that the coefficient estimates for the High and Low samples are the same. 
Panel A: Domestic Amihud

\begin{tabular}{|c|c|c|c|c|c|c|}
\hline & \multicolumn{2}{|c|}{ Beta } & \multirow{2}{*}{ Firms } & \multirow{2}{*}{ R-Squared } & \multirow{2}{*}{ Chow p-value } \\
\hline & & Coeff. & t-stat & & & \\
\hline \multirow{2}{*}{ Multimarket Trading } & High & -0.0167 & -2.09 & 84 & $5.12 \%$ & \multirow{2}{*}{$5.3 \%$} \\
\hline & Low & -0.0009 & -1.38 & 85 & $2.42 \%$ & \\
\hline \multirow{2}{*}{ FirmVolumeIndex } & High & -0.0082 & -1.20 & 91 & $1.73 \%$ & \multirow{2}{*}{$85.1 \%$} \\
\hline & Low & -0.0097 & -2.23 & 91 & $5.9 \%$ & \\
\hline \multirow{2}{*}{ Size } & High & -0.0003 & -1.66 & 82 & $4.0 \%$ & \multirow{2}{*}{$14.3 \%$} \\
\hline & Low & -0.0153 & -1.53 & 82 & $3.1 \%$ & \\
\hline \multirow{2}{*}{ SharesUS } & High & -0.0040 & -1.87 & 49 & $7.9 \%$ & \multirow{2}{*}{$17.5 \%$} \\
\hline & Low & -0.0210 & -1.71 & 50 & $6.0 \%$ & \\
\hline \multirow{2}{*}{ NumberUS } & High & -0.0013 & -2.13 & 54 & $9.0 \%$ & \multirow{2}{*}{$4.2 \%$} \\
\hline & Low & -0.0248 & -2.14 & 60 & $7.8 \%$ & \\
\hline \multirow{2}{*}{ BKLMeasure } & High & -0.0132 & -1.70 & 91 & $3.5 \%$ & \multirow{2}{*}{$31.1 \%$} \\
\hline & Low & -0.004 & -1.75 & 91 & $3.5 \%$ & \\
\hline \multirow{2}{*}{ MarketVolumeIndex } & High & -0.0092 & -1.20 & 87 & $2.0 \%$ & \multirow{2}{*}{$96.1 \%$} \\
\hline & Low & -0.0087 & -2.15 & 97 & $4.9 \%$ & \\
\hline
\end{tabular}

Panel B: Volume-Weighted Amihud

\begin{tabular}{|c|c|c|c|c|c|c|}
\hline & & \multicolumn{2}{|c|}{ Beta } & \multirow{2}{*}{ Firms } & \multirow{2}{*}{ R-Squared } & \multirow{2}{*}{ Chow p-value } \\
\hline & & Coeff. & t-stat & & & \\
\hline \multirow{2}{*}{ Multimarket Trading } & High & -0.0182 & -2.29 & 84 & $6.1 \%$ & \multirow{2}{*}{$3.3 \%$} \\
\hline & Low & -0.0011 & -1.56 & 85 & $3.1 \%$ & \\
\hline \multirow{2}{*}{ FirmVolumeIndex } & High & -0.0097 & -1.44 & 91 & $2.5 \%$ & \multirow{2}{*}{$\begin{array}{l}97 \% \\
\ldots \ldots \ldots\end{array}$} \\
\hline & Low & -0.0100 & -2.28 & 91 & $6.2 \%$ & \\
\hline \multirow[b]{2}{*}{ Size } & High & -0.0004 & -1.80 & 82 & $4.7 \%$ & \multirow{2}{*}{$9.7 \%$} \\
\hline & Low & -0.0135 & -1.71 & 82 & $4.0 \%$ & \\
\hline \multirow{2}{*}{ SharesUS } & High & -0.0043 & -1.91 & 49 & $8.4 \%$ & \multirow{2}{*}{$16.2 \%$} \\
\hline & Low & -0.0221 & -1.76 & 50 & $6.4 \%$ & \\
\hline \multirow{2}{*}{ NumberUS } & High & -0.0013 & -2.15 & 54 & $9.3 \%$ & \multirow{2}{*}{$3.6 \%$} \\
\hline & Low & -0.0266 & -2.20 & 60 & $8.5 \%$ & \\
\hline \multirow{2}{*}{ BKLMeasure } & High & -0.0138 & -1.77 & 91 & $3.8 \%$ & \multirow{2}{*}{$\begin{array}{l}34.1 \% \\
\cdots . . . . . . .\end{array}$} \\
\hline & Low & -0.0062 & -2.28 & 91. & $6.0 \%$ & \\
\hline \multirow{2}{*}{ MarketVolumeIndex } & High & -0.0093 & -1.21 & 87 & $2.0 \%$ & \multirow{2}{*}{$91.0 \%$} \\
\hline & Low & -0.0103 & -2.56 & 97 & $6.8 \%$ & \\
\hline
\end{tabular}




\section{Figure 1 Average Trading Volume Shock Correlations: Emerging Markets versus Developed Markets}

This figure shows equal-weighted average trading volume shock correlations (based on the VAR using daily trading volume changes, CorrVolChange) of firms from emerging and developed countries across time. The straight lines are fitted with OLS.

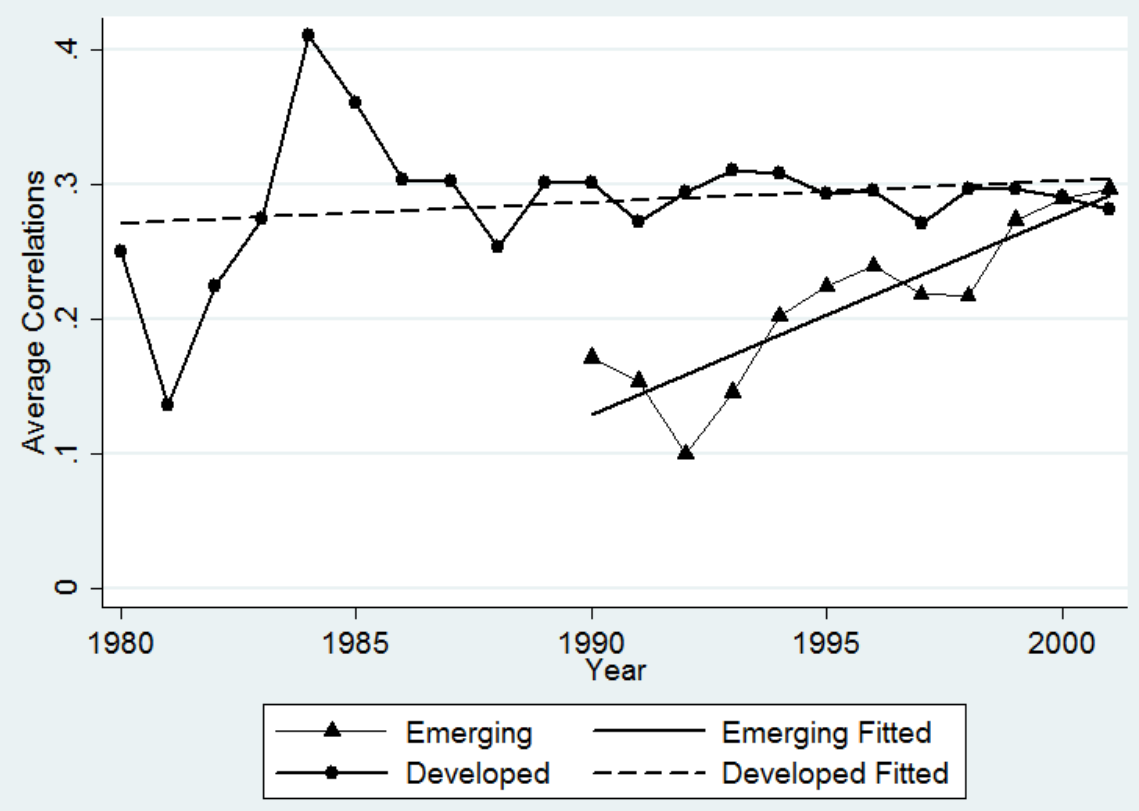




\section{Figure 2 Price Parity vs. Volume Integration}

This figure shows a comparison of price disparity data from Gagnon and Karolyi (2010a) to volume shock correlations for a selection of four countries.
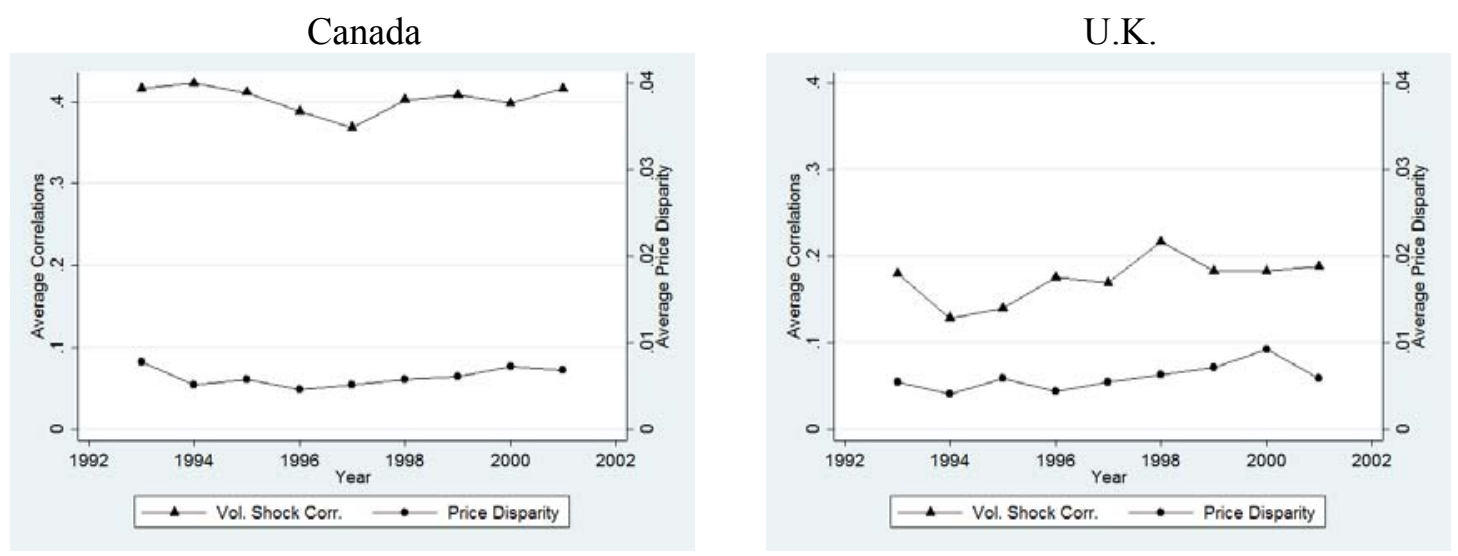

Chile

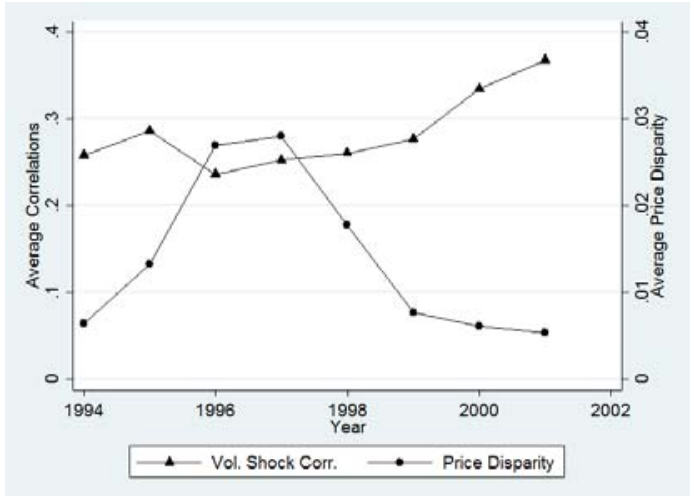

France

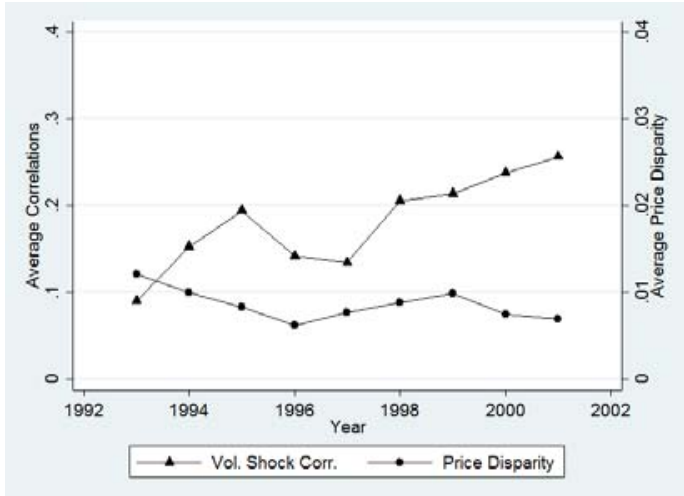


Table A1. Explanation of Variables

\begin{tabular}{|c|c|c|}
\hline Variable & Rationale & Definition \\
\hline \multicolumn{3}{|l|}{ Market-level } \\
\hline Trading hours overlap (Overlap) & $\begin{array}{l}\text { More overlap means more time for investors to split trades } \\
\text { and arbitrageurs to exploit mispricings. }\end{array}$ & $\begin{array}{l}\text { Percentage of domestic trading hours that overlap with } \\
\text { cross-listing trading hours. Source: exchange websites. }\end{array}$ \\
\hline $\begin{array}{l}\text { Trading cost difference } \\
\text { (TCostDiff) }\end{array}$ & $\begin{array}{l}\text { Higher trading cost difference reduces attractiveness of } \\
\text { splitting trades across markets. }\end{array}$ & $\begin{array}{l}\text { Indicator variable taking the value of one if the absolute } \\
\text { difference between total trading costs on the domestic and } \\
\text { cross-listing markets is above the median value of market } \\
\text { pairs, else zero. Source: Chiyachantana et al. (2004). }\end{array}$ \\
\hline Trading cost sum (TCostComb) & $\begin{array}{l}\text { Higher total trading cost reduces profitability of arbitrage } \\
\text { opportunities. }\end{array}$ & $\begin{array}{l}\text { Sum of the total trading costs for domestic and cross-listing } \\
\text { markets. Source: Chiyachantana et al. (2004). }\end{array}$ \\
\hline $\begin{array}{l}\text { Dollar trading volume on cross- } \\
\text { listing/domestic market, measured } \\
\text { as absolute deviation from one } \\
\text { (MarketVolumeIndex) }\end{array}$ & $\begin{array}{l}\text { Larger differences in trading volume (as a proxy for market } \\
\text { liquidity) makes trade-splitting less likely. }\end{array}$ & $\begin{array}{l}\text { Log of the absolute difference between one and the ratio of } \\
\text { total dollar trading volume (for all stocks) on the domestic } \\
\text { and cross-listing markets. Source: Datastream. }\end{array}$ \\
\hline $\begin{array}{l}\text { Total dollar trading volume on } \\
\text { cross-listing and domestic market } \\
\text { (MarketVolumeComb) }\end{array}$ & $\begin{array}{l}\text { Larger total trading volume (as a proxy for market liquidity) } \\
\text { makes arbitrage more likely. }\end{array}$ & $\begin{array}{l}\text { Sum of total dollar trading volume on the domestic and } \\
\text { cross-listing markets. Source: Datastream. }\end{array}$ \\
\hline $\begin{array}{l}\text { Protection against insider trading } \\
\text { in the domestic market } \\
\text { (ITProtect) }\end{array}$ & $\begin{array}{l}\text { Multimarket trading is more likely once anti-insider trading } \\
\text { laws (as a proxy for investor protections more generally) } \\
\text { have been enforced on both markets. }\end{array}$ & $\begin{array}{l}\text { Indicator variable that equals one in year } t \text { if insider trading } \\
\text { laws have been enforced in the home market during or } \\
\text { before year } t \text {, else zero. Source: Bhattacharya and Daouk } \\
(2002) \text {. }\end{array}$ \\
\hline Short sales permitted (ShortSale) & $\begin{array}{l}\text { Short-sale constraints render arbitrage difficult or impossible, } \\
\text { which can allow prices in the cross-listing and domestic } \\
\text { markets to diverge. Thus trade-splitting may also be more } \\
\text { attractive when there are no short-sale constraints. }\end{array}$ & $\begin{array}{l}\text { Indicator variable equal to one in year } t \text { if short sales are } \\
\text { permitted in the domestic market that year, else zero. } \\
\text { (During our sample period short sales were permitted in the } \\
\text { U.S.) Source: Bris, Goetzmann, and Zhu (2007). }\end{array}$ \\
\hline $\begin{array}{l}\text { Market design different } \\
\text { (MktDesignDiff) }\end{array}$ & $\begin{array}{l}\text { When one market has a traditional floor structure while the } \\
\text { other is electronic, trade-splitters and arbitrageurs may find it } \\
\text { more difficult to execute trades in both markets. Difference } \\
\text { in market structure may also serve as a proxy for differential } \\
\text { trading costs (Jain (2005)). }\end{array}$ & $\begin{array}{l}\text { Indicator variable that equals one in year } t \text { if electronic } \\
\text { trading has been introduced in either the domestic market } \\
\text { or the cross-listing market, but not both, before year } t \text {, else } \\
\text { zero. Source: Jain (2005). }\end{array}$ \\
\hline
\end{tabular}


Firm-level

Domestic and US Amihud

illiquidity measures

(DomesticAmihud, USAmihud)

Firm's dollar trading volume on cross-listing/domestic market, measured as absolute deviation from one (FirmVolumeIndex)

Stock return correlation to crosslisting market's return (CLCorr)
When a stock is more liquid, as arbitrage is easier and investors can split their trades with relatively less price impact. As a measure of illiquidity, the Amihud measure is higher for less liquid stocks, so we expect negative coefficients on both Amihud measures, although we recognize that they are highly correlated and thus may not both appear significant.

If a stock is generally not actively traded in one market, it should be relatively costly for investors to split their trades. A stock's average trading volume can also be interpreted as a rough proxy for the number of non-discretionary liquidity traders in each market (e.g., Chowdhry and Nanda (1991)). If there are more liquidity traders in each market, discretionary traders will derive more price-impact benefit from splitting their trades across markets.

If more of a stock's price-relevant public information is revealed when the cross-listing market is open, both tradesplitters and arbitrageurs should trade more actively in both markets. (Ellul, Shin, and Tonks (2005) discuss the importance of the opening of markets, arguing that the market open performs an important information aggregation and price discovery function.) This public information includes firm-specific information such as earnings announcements and industry information such as the performance of major competitors. In general, such information is revealed before or at the time that the domestic market opens, which is before the cross-listing markets in our sample open. These information location factors should affect trading volume shock correlations mainly through price-impact minimization, although if information revelation causes temporary price dislocations it could also boost arbitrage activity.
Absolute value of the daily return on the US (domestic) market divided by the daily volume on the US (domestic) market, then averaged per firm/year. Source: Datastream.

Log of the absolute difference between one and the ratio of the firm's dollar trading volume on the cross-listing market to the domestic market. Source: Datastream.

Stock return correlation to the cross-listing market's return. Measure in year $t$ is calculated using weekly stock returns and cross-listing market index returns from year $t-2$ to year t. Source: Datastream. 
Baruch-Karolyi-Lemmon relative information measure

(BKLMeasure)

Percentage of shares held by U.S. institutions (SharesUS)

Number of U.S. institutions

invested in the firm (NumberUS)

Fraction of firm's sales from foreign markets (ForSales)

Technology sector (TechSec)
Higher BKL measure signals more firm-specific public information being revealed in the cross-listing market, which should lead to more trade-splitting and arbitrage.

Difference in R-squared between regressions of crosslisted stock returns on domestic and cross-listing market index returns and regressions of cross-listed stock returns on only domestic market index returns. Measure in year $t$ is calculated using weekly stock returns and market index returns from year $t-2$ to year $t$. Source: Datastream and Baruch, Karolyi, and Lemmon (2007)

Percentage of shares held by U.S. institutions. Source:

Domestic and cross-listing market volume shocks should be more correlated for firms owned predominantly by institutional investors, who generally have more discretion over their trading location.

Domestic and cross-listing market volume shocks should be Number of shares held by U.S. institutions. Source:

more correlated for firms owned predominantly by Thompson Financial Shareworld

institutional investors, who generally have more discretion over their trading location.

Firms with more of their total sales coming from nondomestic markets develop more of a global following.

Prices of technology-oriented cross-listed firms depend to a large extent on information revealed in the U.S. market (Pagano et al.(2002), Halling et al. (2008)), suggesting higher trading volume shock correlations for technology-oriented firms.

Control variables

Firm size (Size)

Idiosyncratic volatility

(StockVolatility)

Absolute yearly stock return

(Return)

Years since first cross-listed

(CLAge)

Thompson Financial Shareworld.

Fraction of foreign sales, measured in percentage points Source: Worldscope.

Indicator variable that equals one for companies with technology-oriented SIC codes, else zero. Source: GlobalVantage and Worldscope.

Total assets in millions of dollars per year. Source: Global Vantage and Worldscope.

Volatility of the residuals in a regression in which stock returns are regressed on returns of the cross-listing and the domestic market indices. Source: Datastream.

Stock's home-currency log price change over the year. Source: Datastream.

Number of years since the firm was first cross-listed. Source: exchange websites. 